\title{
A PRESENÇA DA LITERATURA TRADUZIDA NO \\ SUPLEMENTO DOMINICAL LITERÁRIO LETRAS \& ARTES (1946-1954)
}

\author{
Eldinar Nascimento Lopes* \\ UFPA \\ eldinarnl@gmail.com
}

\section{Izabela Guimarães Guerra Leal ${ }^{* *}$ \\ UFPA \\ izabelaleal@gmail.com}

RESUMO: O presente trabalho tem por objetivo catalogar as traduções literárias publicadas no suplemento literário Letras \& Artes, do jornal A Manhã, do Estado do Rio de Janeiro, no período compreendido de 1946 a 1954, para dar continuidade e suporte às futuras pesquisas interessadas em analisar as traduções que circularam durante esse momento, bem como avivar as pesquisas acadêmicas nos periódicos brasileiros. Nesse contexto de abertura intercultural - e intelectual de nossa plêiade para outras formas de pensamento -, a presença do tradutor assume um importante papel dentro desse laço transformador, sobretudo, quando se descobre o esforço que nossos escritorestradutores tiveram em divulgar uma literatura cada vez mais ampla, heterogênea e crítica.

Palavras-chave: Tradução. Letras \& Artes. Formação cultural

* Mestranda do Curso de Pós-Graduação em Letras da Universidade Federal do Pará.

${ }^{*}$ Professora do Programa de Pós-Graduação em Letras da Universidade Federal do Pará.

Revista Texto Poético I ISSN: 1808-5385 | Vol. 20 (1o sem-2016) - p. 92 
Historiadores de nossa vida intelectual vão buscar nas páginas do suplemento de A Manhã o frêmito de nossa vida indispensável à compreensão do instante cultural que atravessamos $^{13}$.

Fernando Ferreira de Loanda

Um dos suplementos literários que mais se destacou no contexto brasileiro do pós-guerra foi, certamente, o Letras \& Artes que, segundo o comentário de Luigi Fiorentino na revista italiana Ausonia, seria "la miggiore rivista letteraria del Brasile ${ }^{14}$ ”. Para José Condé $^{15}$, em razão de ser considerada "a mais séria realização já empreendida no Brasil" e por tornar-se "uma verdadeira revista de arte, aplicada na valorização de nossa cultura e na exposição e no debate de nossos problemas estéticos e intelectuais", o caderno, dirigido por Jorge Lacerda, tornou-se uma das principais referências na América Latina para a divulgação, no exterior, de expressões e valores estéticos nacionais e para a expansão cultural em razão de uma abertura à escrita e ao pensamento estrangeiros, o que tornou a tradução uma das principais protagonistas desse suplemento.

A diversidade de poemas, contos, textos críticos, divulgação de livros traduzidos, entrevistas com os tradutores, até mesmo de ensaios debatendo sobre o valor da tradução, foi muito importante não somente para valorizar o trabalho do tradutor como também expor ao leitor a importância da circulação da literatura mundial para cultura brasileira. Nesse contexto de abertura intercultural e

${ }^{13}$ Manifestação recebida no $2^{\circ}$ aniversário do Suplemento Literário Letras \& Artes, 1948, ano III, ed. 85, p. 10.16 de maio de 1948

${ }^{14}$ LETRAS \& ARTES, 1948, ano III, ed. 96, p.2, 22 de agosto de 1948.

${ }^{15}$ DE CONDÉ, José, Letras \& Artes, 1947, ano II, ed. 41, p.3, 11 de maio de 1947.

Revista Texto Poético I ISSN: 1808-5385 | Vol. 20 (1o sem-2016) - p. 93 
intelectual para outras formas de pensamento, a presença do tradutor assume um importante papel como agente transformador, sobretudo, quando se descobre o esforço que nossos escritores-tradutores tiveram em divulgar uma literatura cada vez mais ampla, heterogênea e crítica, ambicionando, assim, trabalhar a pluralidade cultural como uma abertura para a transformação do conhecimento. Tanto é que, no ano de 1951, o suplemento insistia na necessidade de ser instituído, no Brasil, um "Prêmio para Tradutores", a ser conferido à melhor tradução do ano ${ }^{16}$.

Nesse sentido, as traduções divulgadas no Letras \& Artes podem ser entendidas como um terreno de aprendizagem cujas regras admitem a coexistência, em igualdade, dos diferentes. Sem esquecer, contudo, que os escritores selecionados por todos os tradutores representam grande importância no cenário literário e, sobretudo, representam grandes figuras históricas e políticas que participaram ativamente de uma militância social e ideológica, ou seja, são autores-chave para a ressurreição de uma grande consciência nacional, o que é comentado pelo escritor e colaborador Edgard Cavalheiro nesse caderno em 1946:

Em pleno Estado Novo, por volta de 1941-42, era proibido, como todos sabem, falar em Democracia. O DIP era rigoroso, mas seus escribas e policiais eram, em compensação, de uma burrice fenomenal. Eles proibiam louvores à Democracia, mas a gente escapulia de mil e uma maneiras. Uma delas, era falar mal do fascismo, ou exaltar vítimas desse mesmo nefando fascismo. Elogiar [García] Lorca, em 41 ou 42, era pretexto para meter a ronca em Franco e na Falange, e por tabela, no Getúlio e Estado Novo. O Fascismo é inimigo da Poesia! Era uma boa fase que reunia o verdadeiro ao útil. Colaborador mais ou

${ }^{16}$ EDITOR. Suplemento Letras \& Artes. Rio de Janeiro, ano IV, ed. 207, 20 maio 1951. Revista Texto Poético I ISSN: 1808-5385 | Vol. 20 (1o sem-2016) - p. 94 
menos assíduo da imprensa paulista, obrigado a "cavar" assuntos, e assuntos de ordem literária, está claro, o assunto Lorca tinha que se impor. Acontece que o poeta era mais do que um bom pretexto: era, realmente, um grande poeta, um grande dramaturgo, a maior figura da Espanha contemporânea. ${ }^{17}$

Sobre a presença do tradutor, é possível dizer que o volume de colaboradores atuando nesse semanário foi surpreendente: ao todo foram 94 escritores, dos quais muitos colaboravam diversas vezes, como Dora Ferreira, Guilherme de Almeida e Manuel Bandeira. Vemos, portanto, que os próprios tradutores eram escritores renomados, e isso, de todo modo, foi muito importante por dignificar a imagem do suplemento. Ora, o jornal prezava por um prestígio social, afinal, era lido por políticos e letrados, e mostrar excelentes escritores da mais alta categoria fluentes em outras línguas confere credibilidade tanto para o trabalho do tradutor quanto para a reputação da gazeta.

E isso talvez já seria uma forma sutil de diferenciar qual tipo de leitor tem acesso ao suplemento: um leitor que sabe julgar se a tradução é boa ou ruim e que muito provavelmente poderia conhecer a língua estrangeira, ou mesmo ser um leitor estrangeiro.

O Campeonato Acadêmico de Tradução ${ }^{18}$ ilustra bem isso. Embora tenha sido publicado apenas em duas edições do suplemento Letras \& Artes, a finalidade do jogo consistiria em exibir ao leitor diferentes formas de traduções provenientes de um único poema. A obra estrangeira foi escolhida pelo ex-ministro do Supremo Tribunal Federal, Ataulfo de Paiva, e os participantes apresentariam suas

${ }^{17}$ CAVALHEIRO, Edgard. Suplemento Letras \& Artes, Rio de Janeiro, ano I, ed. 17, 6 out. 1946.

${ }^{18}$ O Campeonato Acadêmico de Tradução. Suplemento Letras \& Artes, Rio de Janeiro, ano IV, ed. 149, $1^{\circ}$ jan. 1950.

Revista Texto Poético | ISSN: 1808-5385 | Vol. 20 (1o sem-2016) - p. 95 
versões para serem "julgadas” pelo público e, claro, por Paiva. Gustavo Barroso, Olegário Mariano e Manuel Bandeira atenderam ao pedido do ex-ministro e propuseram a tradução de um poema francês. Essa "brincadeira" produz um grande efeito positivo às nossas letras, visto que desperta o leitor para a construção de uma rede discursiva dinâmica, variável e interativa das obras traduzidas, isto é, o leitor não somente poderia decidir qual tradução mais lhe agradou como também "participar da brincadeira" escrevendo sua versão e encaminhando à Redação.

Sobre isso, em termos comparativos com a escrita estrangeira, mostra-nos quão criativos e inovadores são os nossos homens de letras, sobretudo por revelar as múltiplas possibilidades de manipulação do texto fonte. Podemos dizer então que esses "propósitos" afastam, assim, o pensamento atravancador de que a nossa literatura, por não sermos falantes do francês ou do inglês, enquadra-se sempre em uma perspectiva periférica, de apagamento - para não falar de desprestígio - diante dos tão conhecidos escritores franceses e ingleses. Essa foi, aliás, a justificativa interpretada por Manuel Bandeira acerca da desvalorização das nossas letras no contexto mundial:

Parece-me que poetas como Carlos Drummond de Andrade, Murilo Mendes, Schmidt, Augusto Meyer, Vinícius e outros estão em pé de igualdade com um Éluard ou um Aragon, na França, ou um Spender e um Auden, na Inglaterra. Os nossos teriam certamente o renome universal dos outros, se o nosso idioma tivesse a universalidade do francês e do inglês ${ }^{19}$.

${ }^{19}$ LETRAS E ARTES. A Manhã, ano I, ed. 13, 25 agosto de 1946. 
Outro recurso importante lançado pelos suplementos para a valorização do escritor nacional foi o de, no geral, publicar as traduções ao lado das produções literárias brasileiras, não havendo, portanto, distinção. Percebe-se, então, certo grau de aproximação não no sentido ipsis litteris da palavra, mas no pensamento de que, em uma mesma edição, as nossas literaturas, a nossa língua, o nosso modo de percepção da vida e a nossa estética compartilhavam o mesmo espaço com outras literaturas e outros modos de escrita literária, sejam obras desconhecidas estrangeiras ao lado de obras de autores canônicos brasileiros, sejam produções de escritores novatos ao lado de obras estrangeiras famosas. Isso não somente demonstra respeito pela nossa escrita, valorizando-a, mas também denota certo grau de comparação, permitindo com que as nossas letras nacionais estejam em pé de igualdade com célebres escritores da literatura mundial. $\mathrm{Ou}$, ao contrário, escritores estrangeiros é que estão em pé de igualdade com os nossos. Pois, como alega Peter Burke (2008, p. 91), "as aparências da página impressa funcionam como uma série de deixas para os leitores, encorajando-os a interpretar o texto de uma maneira e não de outra".

Em vista disso, devemos notar, mesmo rapidamente, que essa forma de pensamento situada quase como um pêndulo de leitura, em que o leitor faz movimentos cheios de idas e vindas, notabiliza-se não somente pelas riquezas culturais e literárias propiciadas por esse tipo de edição, como também pelo trabalho de análise crítica dos leitores perante as obras. Ao percebermos que esse tipo de estrutura se realiza como um importante disseminador de ideologia e de uma forma diferente de percepção sobre as nossas letras, considera-se que os suplementos não poderiam ser destinados a qualquer leitor, 
mesmo que sua inserção se dê em um dos veículos de comunicação mais acessíveis e populares da época.

Esse emparelhamento das literaturas nacional e estrangeira, posto quase como uma prova à qualidade de nossa escrita, alinha-se também a outra questão que diz respeito à formação cultural a partir do contato com outros costumes, e que diretamente levanta a discussão sobre a formação da história brasileira: essas diversas literaturas abordadas no suplemento vieram incorporar ao pensamento do circuito brasileiro novas transformações no modo de ler e sentir o texto literário, sugerindo novas composições que permitem uma crítica verdadeiramente universal, intensamente cosmopolita ao campo da literatura, do conhecimento e, especialmente da cultura, pois, como bem destaca Homi Bhabha (2013, p.21), a diferença cultural não se classifica como algo conceitualmente estático, mas articula-se sempre na flexibilidade de sujeitos, pensamentos, tempos, ideais:

Representação da diferença não deve ser lida apressadamente como reflexo de traços culturais ou étnicos preestabelecidos, inscritos na lápide fixa da tradição. A articulação social da diferença (...) é uma negociação complexa, em andamento, que procura conferir autoridade aos hibridismos culturais que emergem em momentos de transformação histórica (...) Ao reencontrar o passado, este introduz outras temporalidades culturais incomensuráveis na invenção da tradição. Esse processo afasta qualquer acesso imediato a uma identidade original ou a uma tradição "recebida". Os embates de fronteira acerca da diferença cultural têm tanta possibilidade de serem consensuais quanto conflituosos; podem confundir nossas definições de tradição e modernidade, realinhar as fronteiras habituais entre o público e o privado, o alto e o baixo, assim como desafiar as expectativas normativas de desenvolvimento e progresso. 
Isso quer dizer que, à medida que a hibridez, os espaços multiculturais e o cosmopolitismo literário oriundos pela tradução se disseminam nesse caderno, a identidade brasileira pode ser vista como um emaranhado de domínios que traçam um estado sempre de construção do presente, inovação do passado e criação do futuro a partir do momento que anexa à sua cultura obras como Stéphane Mallarmé, Cervantes, Thomas Mann, Victor Hugo, Anton Tchekhov e outros, ao lado de Vinicius de Moraes, de Murilo Mendes, de Andréa Gama Fernandes, de Lia Dutra, de Rosário Fusco, de Haroldo Maranhão, de Dinah Silveira de Queiroz, de José Simeão etc. E conduzir os leitores a essa política construtiva, em que são estabelecidos elos políticos, sociais e estéticos, compreendendo principalmente o presente como canal indissociável do passado, aponta certa maneira de entender a realidade que nos cerca, pois, "além de atuarem no processo de formação e transformação de uma literatura nacional como gestos antropofágicos de tradição e culturas que passam pelo estrangeiro e pelo próprio" (GUIMARÃES, 2013,p.44), são também reconhecidos traços que marcam o discurso como moderno, visto que esses deslocamentos de escritas passadas partem de uma releitura com o presente e de um diálogo com a nossa cultura, pois está claro que a literatura traduzida toma determinados contornos significativos na sociedade, pois projeta para a cultura acolhedora toda uma forma de pensamento e de vida estrangeiros que sugerem outras formas de reflexões para a sua própria formação e, ao mesmo tempo, permite que a cultura que está sendo revelada e introduzida seja desdobrada em novas construções críticas de compreensão do mundo, da história, da escrita, do homem, de outras formas de sentimento. 
O suplemento literário Letras \& Artes iniciou suas atividades em 1946 e parou em 1954. Na conjuntura mundial, foi um período bastante problemático no que se refere às experiências e às relações humanas causadas pelo trauma das grandes guerras mundiais, e para o contexto brasileiro foi um momento de "abertura" do período varguista, ou seja, o momento era propício para se discutir sobre liberdade, democracia e sociedade em um tempo em que o homem mudou o modo de atuar e de refletir diante das novas transformações que ocorreram nos espaços da política, da economia, da ciência, da tecnologia, da geografia, do tempo. De um modo geral, as obras literárias traduzidas refletem isso. 
Catalogação dos textos literários traduzidos (de 1946 a 1954)

\section{6}

Quadro 1: esquematização das traduções publicadas no ano de 1946 no suplemento Letras \& Artes

\begin{tabular}{|c|c|c|c|c|c|c|c|c|}
\hline $\mathrm{ANO} / \mathbf{N}^{\circ}$ & $\frac{\sum}{\frac{2}{2}}$ & 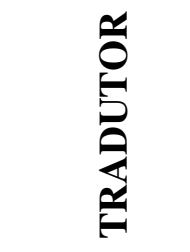 & 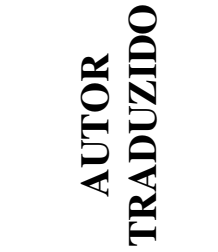 & 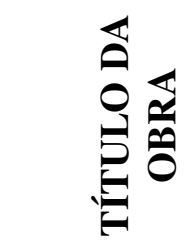 & $\sum_{\substack{x=1 \\
0}}^{S}$ & 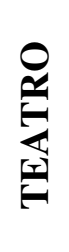 & 岂 & 号 \\
\hline $\begin{array}{l}\text { Suplemento Letras \& } \\
\text { Artes. A Manhã, ano VI, } \\
\text { ed. } 7,30 \text { de junho de } \\
1946\end{array}$ & Alemão & $\begin{array}{l}\text { Tasso da } \\
\text { Silveira }\end{array}$ & $\begin{array}{l}\text { Gertrud Von } \\
\text { Le Fort }\end{array}$ & I e II & 2 & & & \\
\hline $\begin{array}{l}\text { Suplemento Letras \& } \\
\text { Artes. A Manhã, ano VI, } \\
\text { ed. } 8,14 \text { de julho de } \\
1946\end{array}$ & $\begin{array}{l}\text { Espanhol } \\
\text { (Bolívia) }\end{array}$ & $\begin{array}{l}\text { Ascendino } \\
\text { Leite }\end{array}$ & $\begin{array}{l}\text { Botelho } \\
\text { Gozalvez }\end{array}$ & $\begin{array}{l}\text { Sangue no } \\
\text { Trópico }\end{array}$ & & & & 1 \\
\hline
\end{tabular}

Revista Texto Poético | ISSN: 1808-5385 | Vol. 20 (1o sem-2016) - p. 101 


\begin{tabular}{|c|c|c|c|c|c|c|}
\hline $\begin{array}{l}\text { Suplemento Letras \& } \\
\text { Artes. A Manhã, ano VI, } \\
\text { ed. } 9,21 \text { de julho de } \\
1946\end{array}$ & Russo & $\begin{array}{l}\text { Manuel } \\
\text { Bandeira }\end{array}$ & $\begin{array}{l}\text { Anton } \\
\text { Tchekhov }\end{array}$ & Vanka & & 1 \\
\hline $\begin{array}{l}\text { Suplemento Letras \& } \\
\text { Artes. A Manhã, ano VI, } \\
\text { ed. } 9,21 \text { de julho de } \\
1946\end{array}$ & Alemão & $\begin{array}{l}\text { Dora } \\
\text { Ferreira da } \\
\text { Silva }\end{array}$ & $\begin{array}{l}\text { Rainer Maria } \\
\text { Rilke }\end{array}$ & $\begin{array}{l}\text { Oitava } \\
\text { Elegia de } \\
\text { Duíno }\end{array}$ & 1 & \\
\hline $\begin{array}{l}\text { Suplemento Letras \& } \\
\text { Artes. A Manhã, ano VI, } \\
\text { ed. } 11,11 \text { de agosto de } \\
1946\end{array}$ & $\begin{array}{l}\text { Espanhol } \\
\text { (Argentina) }\end{array}$ & $\begin{array}{l}\text { Acácio } \\
\text { França }\end{array}$ & $\begin{array}{l}\text { Roberto } \\
\text { Payró }\end{array}$ & $\begin{array}{l}\text { Adão e o } \\
\text { Macaco }\end{array}$ & & 1 \\
\hline $\begin{array}{l}\text { Suplemento Letras \& } \\
\text { Artes. A Manhã, ano VI, } \\
\text { ed. } 14,8 \text { de setembro de } \\
1946\end{array}$ & Alemão & $\begin{array}{l}\text { Dora } \\
\text { Ferreira } \\
\text { Silva }\end{array}$ & $\begin{array}{l}\text { Rainer Maria } \\
\text { Rilke }\end{array}$ & $\begin{array}{l}\text { Nona Elegia } \\
\text { de Duíno }\end{array}$ & 1 & \\
\hline
\end{tabular}

Revista Texto Poético | ISSN: 1808-5385 | Vol. 20 (1o sem-2016) - p. 102 


\begin{tabular}{|c|c|c|c|c|c|c|}
\hline $\begin{array}{l}\text { Suplemento Letras \& } \\
\text { Artes. A Manhã, ano VI, } \\
\text { ed. 14, } 8 \text { de setembro de } \\
1946\end{array}$ & $\begin{array}{l}\text { Inglês } \\
\text { (Inglaterra) }\end{array}$ & $\begin{array}{l}\text { Eugênio } \\
\text { Gomes }\end{array}$ & $\begin{array}{l}\text { John } \\
\text { Galsworthy }\end{array}$ & Filantropia & & 1 \\
\hline $\begin{array}{l}\text { Suplemento Letras \& } \\
\text { Artes. A Manhã, ano VI, } \\
\text { ed. } 15,15 \text { de setembro } \\
\text { de } 1946\end{array}$ & Francês & $\begin{array}{l}\text { Xavier } \\
\text { Placer }\end{array}$ & $\begin{array}{l}\text { Arthur } \\
\text { Rimbaud }\end{array}$ & $\begin{array}{l}\text { Os corvos; e } \\
\text { Realeza }\end{array}$ & 1 & 1 \\
\hline $\begin{array}{l}\text { Suplemento Letras \& } \\
\text { Artes. A Manhã, ano VI, } \\
\text { ed. } 18,13 \text { de outubro de } \\
1946\end{array}$ & $\begin{array}{l}\text { Inglês } \\
\text { (Estados } \\
\text { Unidos) }\end{array}$ & $\begin{array}{l}\text { Bezerra de } \\
\text { Freitas }\end{array}$ & $\begin{array}{l}\text { Andrew } \\
\text { Preston } \\
\text { Peabody }\end{array}$ & Pensamento & 1 & \\
\hline $\begin{array}{l}\text { Suplemento Letras \& } \\
\text { Artes. A Manhã, ano VI, } \\
\text { ed. } 20,2 \text { de novembro } \\
\text { de } 1946\end{array}$ & Francês & $\mathrm{x}$ & $\begin{array}{l}\text { Charles } \\
\text { Baudelaire }\end{array}$ & $\begin{array}{l}\text { O mau } \\
\text { vidraceiro }\end{array}$ & & 1 \\
\hline
\end{tabular}

Revista Texto Poético | ISSN: 1808-5385 | Vol. 20 (1o sem-2016) - p. 103 


\begin{tabular}{|c|c|c|c|c|c|c|c|}
\hline $\begin{array}{l}\text { Suplemento Letras \& } \\
\text { Artes. A Manhã, ano VI, } \\
\text { ed. } 23,1^{\circ} \text { de dezembro } \\
\text { de } 1946\end{array}$ & Alemão & $\begin{array}{l}\text { Manuel } \\
\text { Bandeira }\end{array}$ & $\begin{array}{l}\text { Rainer Maria } \\
\text { Rilke }\end{array}$ & $\begin{array}{l}\text { Torso } \\
\text { Arcaico de } \\
\text { Apolo, do } \\
\text { volume } \\
\text { Poemas } \\
\text { Novos }\end{array}$ & & & 1 \\
\hline $\begin{array}{l}\text { Suplemento Letras \& } \\
\text { Artes. A Manhã, ano VI, } \\
\text { ed. } 25,15 \text { de dezembro } \\
\text { de } 1946\end{array}$ & $\begin{array}{l}\text { Espanhol } \\
\text { (Espanha) }\end{array}$ & $\begin{array}{l}\text { Álvaro } \\
\text { Gonçalvez }\end{array}$ & $\begin{array}{l}\text { Luigi } \\
\text { Fiorentino }\end{array}$ & Pares & & 1 & \\
\hline $\begin{array}{l}\text { Suplemento Letras \& } \\
\text { Artes. A Manhã, ano VI, } \\
\text { ed. } 14,14 \text { de abril de } \\
1946\end{array}$ & Alemão & $\begin{array}{l}\text { Dora } \\
\text { Ferreira da } \\
\text { Silva }\end{array}$ & $\begin{array}{l}\text { Rainer Maria } \\
\text { Rilke }\end{array}$ & $\begin{array}{l}\text { Quarta } \\
\text { Elegia de } \\
\text { Duíno }\end{array}$ & 1 & & \\
\hline $\begin{array}{l}\text { Suplemento Letras \& } \\
\text { Artes. A Manhã, ano VI, } \\
\text { ed. } 14,14 \text { de abril de } \\
1946\end{array}$ & Alemão & $\begin{array}{l}\text { Dora } \\
\text { Ferreira da } \\
\text { Silva }\end{array}$ & $\begin{array}{l}\text { Rainer Maria } \\
\text { Rilke }\end{array}$ & $\begin{array}{l}\text { Terceira } \\
\text { Elegia de } \\
\text { Duíno }\end{array}$ & 1 & & \\
\hline
\end{tabular}

Revista Texto Poético | ISSN: 1808-5385 | Vol. 20 (1o sem-2016) - p. 104 


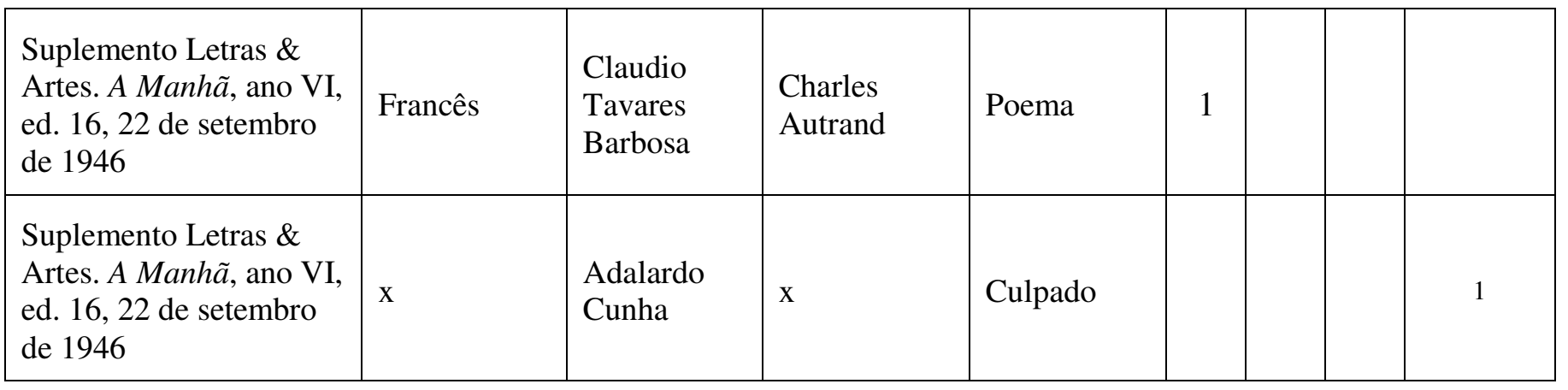




\section{7}

Quadro 2: esquematização das traduções publicadas no ano de 1947 no suplemento Letras \& Artes

\begin{tabular}{|c|c|c|c|c|c|c|c|c|}
\hline $\mathrm{ANO} / \mathbf{N}^{\circ}$ & 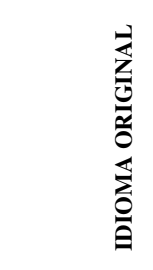 & 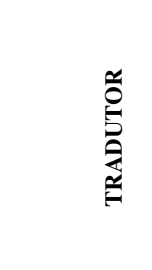 & 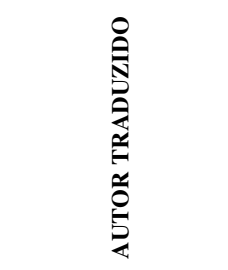 & 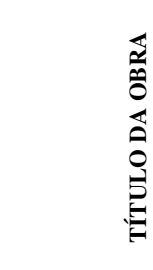 & 产 & 里 & & $\begin{array}{l}0 \\
z \\
0 \\
0\end{array}$ \\
\hline $\begin{array}{l}\text { Suplemento Letras \& } \\
\text { Artes. A Manhãa, ano II, } \\
\text { ed. 30, } 2 \text { de fevereiro de } \\
1947\end{array}$ & Indiano & $\begin{array}{l}\text { Abgard } \\
\text { Renault }\end{array}$ & $\begin{array}{l}\text { Rabindranath } \\
\text { Tagore }\end{array}$ & $\begin{array}{l}\text { Pássaros } \\
\text { perdidos }\end{array}$ & 1 & & & \\
\hline
\end{tabular}




\begin{tabular}{|c|c|c|c|c|c|c|}
\hline $\begin{array}{l}\text { Suplemento Letras \& } \\
\text { Artes. A Manhã, ano VI, } \\
\text { ed. } 33,2 \text { de fevereiro de } \\
1947\end{array}$ & Alemão & $\begin{array}{l}\text { Dora } \\
\text { Ferreira da } \\
\text { Silva }\end{array}$ & $\begin{array}{l}\text { Rainer Maria } \\
\text { Rilke }\end{array}$ & $\begin{array}{l}\text { Décima } \\
\text { Elegia de } \\
\text { Duíno }\end{array}$ & 1 & \\
\hline $\begin{array}{l}\text { Suplemento Letras \& } \\
\text { Artes. A Manhã, ano VI, } \\
\text { ed. } 50,3 \text { de agosto de } \\
1947\end{array}$ & $\begin{array}{l}\text { Inglês } \\
\text { (Inglaterra) }\end{array}$ & $\begin{array}{l}\text { Bezerra de } \\
\text { Freitas }\end{array}$ & John Ruskin & $\begin{array}{l}\text { Opiniões de } \\
\text { Ruskin }\end{array}$ & & 1 \\
\hline $\begin{array}{l}\text { Suplemento Letras \& } \\
\text { Artes. A Manhã, ano VI, } \\
\text { ed. } 37,6 \text { de abril de } \\
1947\end{array}$ & Francês & $\mathrm{x}$ & $\begin{array}{l}\text { Apenas } \\
\text { autor: } \\
\text { François } \\
\text { Maynard }\end{array}$ & $\begin{array}{l}\text { En } \\
\text { Attendant } \\
\text { la mort }\end{array}$ & 1 & \\
\hline
\end{tabular}




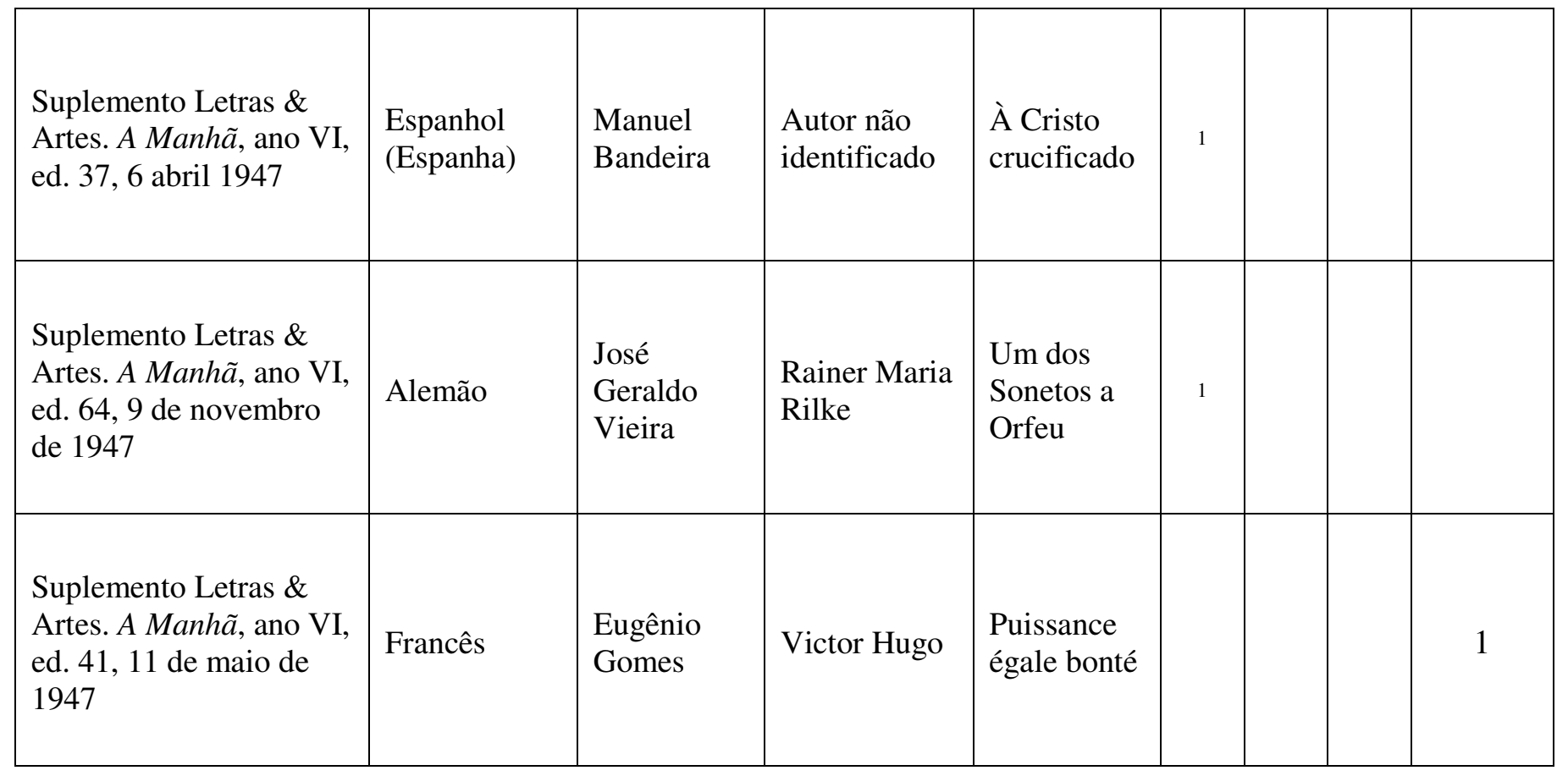

Revista Texto Poético | ISSN: 1808-5385 | Vol. 20 (1o sem-2016) - p. 108 


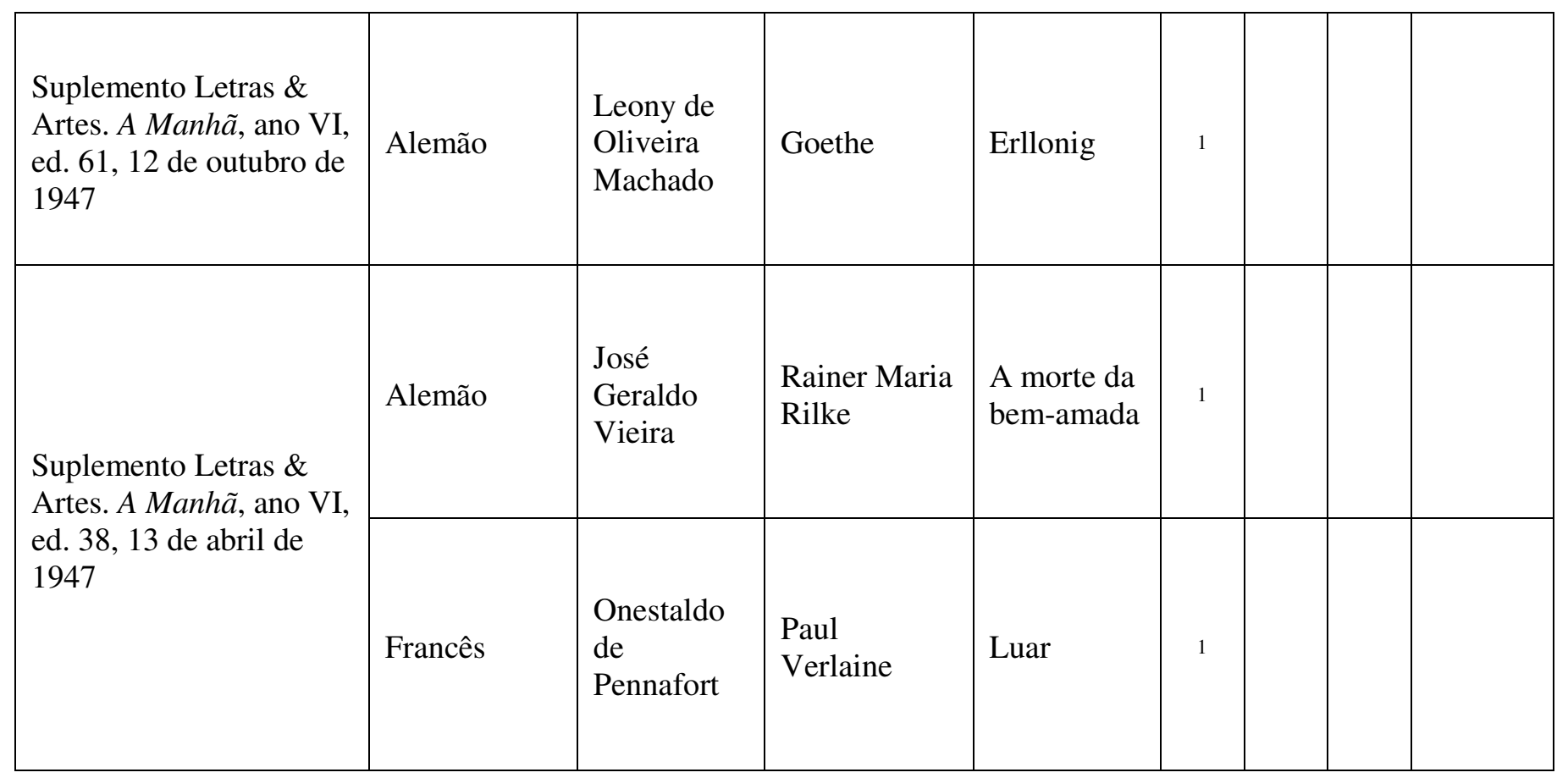

Revista Texto Poético | ISSN: 1808-5385 | Vol. 20 (1o sem-2016) - p. 109 


\begin{tabular}{|c|c|c|c|c|c|c|}
\hline & & $\begin{array}{l}\text { Guilherme } \\
\text { de Almeida }\end{array}$ & $\begin{array}{l}\text { Stéphane } \\
\text { Mallarmé }\end{array}$ & $\begin{array}{l}\text { Brisa } \\
\text { Marinha }\end{array}$ & 1 & \\
\hline & & $\begin{array}{l}\text { Celso } \\
\text { Vieira }\end{array}$ & $\begin{array}{l}\text { Arthur } \\
\text { Rimbaud }\end{array}$ & As vogais & 1 & \\
\hline $\begin{array}{l}\text { Suplemento Letras \& } \\
\text { Artes. A Manhã ano VI, } \\
\text { ed. 32, } 16 \text { de fevereiro } \\
\text { de } 1947\end{array}$ & Alemão & $\begin{array}{l}\text { Lúcio } \\
\text { Cardoso }\end{array}$ & $\begin{array}{l}\text { Rainer Maria } \\
\text { Rilke }\end{array}$ & Rilkeana & & 1 \\
\hline
\end{tabular}

Revista Texto Poético | ISSN: 1808-5385 | Vol. 20 (1o sem-2016) - p. 110 


\begin{tabular}{|c|c|c|c|c|c|c|}
\hline $\begin{array}{l}\text { Suplemento Letras \& } \\
\text { Artes. A Manhã, ano VI, } \\
\text { ed. } 51,17 \text { de agosto de } \\
1947\end{array}$ & Francês & $\begin{array}{l}\text { Manuel } \\
\text { Bandeira }\end{array}$ & $\begin{array}{l}\text { Francis } \\
\text { James }\end{array}$ & $\begin{array}{l}\text { Meu } \\
\text { humilde } \\
\text { amigo }\end{array}$ & 1 & \\
\hline $\begin{array}{l}\text { Suplemento Letras \& } \\
\text { Artes. A Manhã, ano VI, } \\
\text { ed. } 62,19 \text { de outubro de } \\
1947\end{array}$ & $\begin{array}{l}\text { Espanhol } \\
\text { (Uruguai) }\end{array}$ & $\begin{array}{l}\text { Catharina } \\
\text { Cannabrava }\end{array}$ & $\begin{array}{l}\text { José Enrique } \\
\text { Rodó }\end{array}$ & $\begin{array}{l}\text { A filosofia } \\
\text { do D. } \\
\text { Quixote e o } \\
\text { descobrime } \\
\text { nto da } \\
\text { América }\end{array}$ & & 1 \\
\hline $\begin{array}{l}\text { Suplemento Letras \& } \\
\text { Artes. A Manhã, ano VI, } \\
\text { ed. } 62,19 \text { de outubro de } \\
1947\end{array}$ & $\begin{array}{l}\text { Espanhol } \\
\text { (Espanha) }\end{array}$ & $\begin{array}{l}\text { Napoleão } \\
\text { Agustín } \\
\text { Lopes }\end{array}$ & $\begin{array}{l}\text { Miguel de } \\
\text { Unamuno }\end{array}$ & $\begin{array}{l}\text { O encontro } \\
\text { de Quixote } \\
\text { com a falsa } \\
\text { Dulcinea }\end{array}$ & & \\
\hline
\end{tabular}

Revista Texto Poético | ISSN: 1808-5385 | Vol. 20 (1o sem-2016) - p. 111 


\begin{tabular}{|c|c|c|c|c|c|c|}
\hline $\begin{array}{l}\text { Suplemento Letras \& } \\
\text { Artes. A Manhã, ano VI, } \\
\text { ed. } 62,19 \text { de outubro de } \\
1947\end{array}$ & Inglês & $\begin{array}{l}\text { Bezerra de } \\
\text { Freitas }\end{array}$ & Oscar Wilde & $\begin{array}{l}\text { Cousas que } \\
\text { Wilde } \\
\text { realmente } \\
\text { disse }\end{array}$ & & 1 \\
\hline $\begin{array}{l}\text { Suplemento Letras \& } \\
\text { Artes. A Manhã, ano VI, } \\
25 \text { de maio de } 1947\end{array}$ & Francês & Brito Broca & Sainte-Beuve & $\begin{array}{l}\text { Os venenos } \\
\text { de Sainte- } \\
\text { Beuve }\end{array}$ & & \\
\hline $\begin{array}{l}\text { Suplemento Letras \& } \\
\text { Artes. A Manhã, ano VI, } \\
\text { ed. } 39,27 \text { de abril de } \\
1947\end{array}$ & Francês & $\begin{array}{l}\text { Abgar } \\
\text { Renault }\end{array}$ & $\begin{array}{l}\text { Abgar } \\
\text { Renault }\end{array}$ & Cultes & & \\
\hline
\end{tabular}

Revista Texto Poético | ISSN: 1808-5385 | Vol. 20 (1o sem-2016) - p. 112 


\begin{tabular}{|c|c|c|c|c|c|c|}
\hline $\begin{array}{l}\text { Suplemento Letras \& } \\
\text { Artes. A Manhã, ano VI, } \\
\text { ed. } 60,28 \text { de setembro } \\
\text { de } 1947\end{array}$ & Francês & Brito Broca & $\begin{array}{l}\text { Antoine } \\
\text { Rivarol }\end{array}$ & $\begin{array}{l}\text { O espírito } \\
\text { de Rivarol }\end{array}$ & 1 & \\
\hline $\begin{array}{l}\text { Suplemento Letras \& } \\
\text { Artes. A Manhã, ano VI, } \\
\text { ed. 39, } 27 \text { de abril de } \\
1947\end{array}$ & Inglês & $\begin{array}{l}\text { Maria } \\
\text { Amélia } \\
\text { Salgado } \\
\text { Loureiro }\end{array}$ & Oscar Wilde & O jovem rei & & 1 \\
\hline $\begin{array}{l}\text { Suplemento Letras \& } \\
\text { Artes. A Manhã, ano II, } \\
\text { ed. } 36,30 \text { de fevereiro } \\
\text { de } 1947\end{array}$ & Russo & $\begin{array}{l}\text { Xavier } \\
\text { Placer }\end{array}$ & $\begin{array}{l}\text { Anton } \\
\text { Tchekhov }\end{array}$ & $\begin{array}{l}\mathrm{O} \\
\text { candelabro }\end{array}$ & & 1 \\
\hline
\end{tabular}

Revista Texto Poético | ISSN: 1808-5385 | Vol. 20 (1o sem-2016) - p. 113 


\section{8}

Quadro 3: esquematização das traduções publicadas no ano de 1948 no suplemento Letras \& Artes

\begin{tabular}{|c|c|c|c|c|c|c|c|c|}
\hline $\mathrm{ANO} / \mathrm{N}^{\circ}$ & 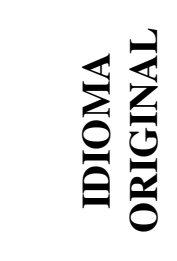 & 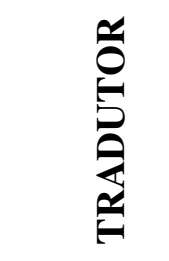 & 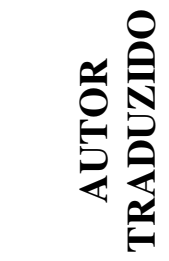 & 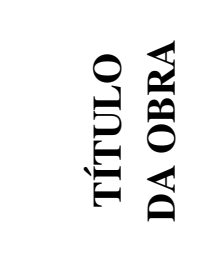 & 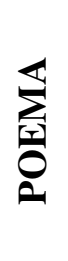 & 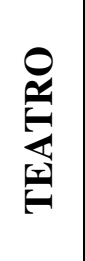 & 岂 & 号 \\
\hline $\begin{array}{l}\text { Suplemento Letras } \\
\& \text { Artes. A Manhã } \\
\text { ano II, ed. } 76,18 \text { de } \\
\text { fevereiro de } 1948\end{array}$ & Inglês & $\begin{array}{l}\text { Maria da } \\
\text { Saudade } \\
\text { Cortesão }\end{array}$ & $\begin{array}{l}\text { David } \\
\text { Gascoyne }\end{array}$ & O Barranco & 1 & & & \\
\hline
\end{tabular}




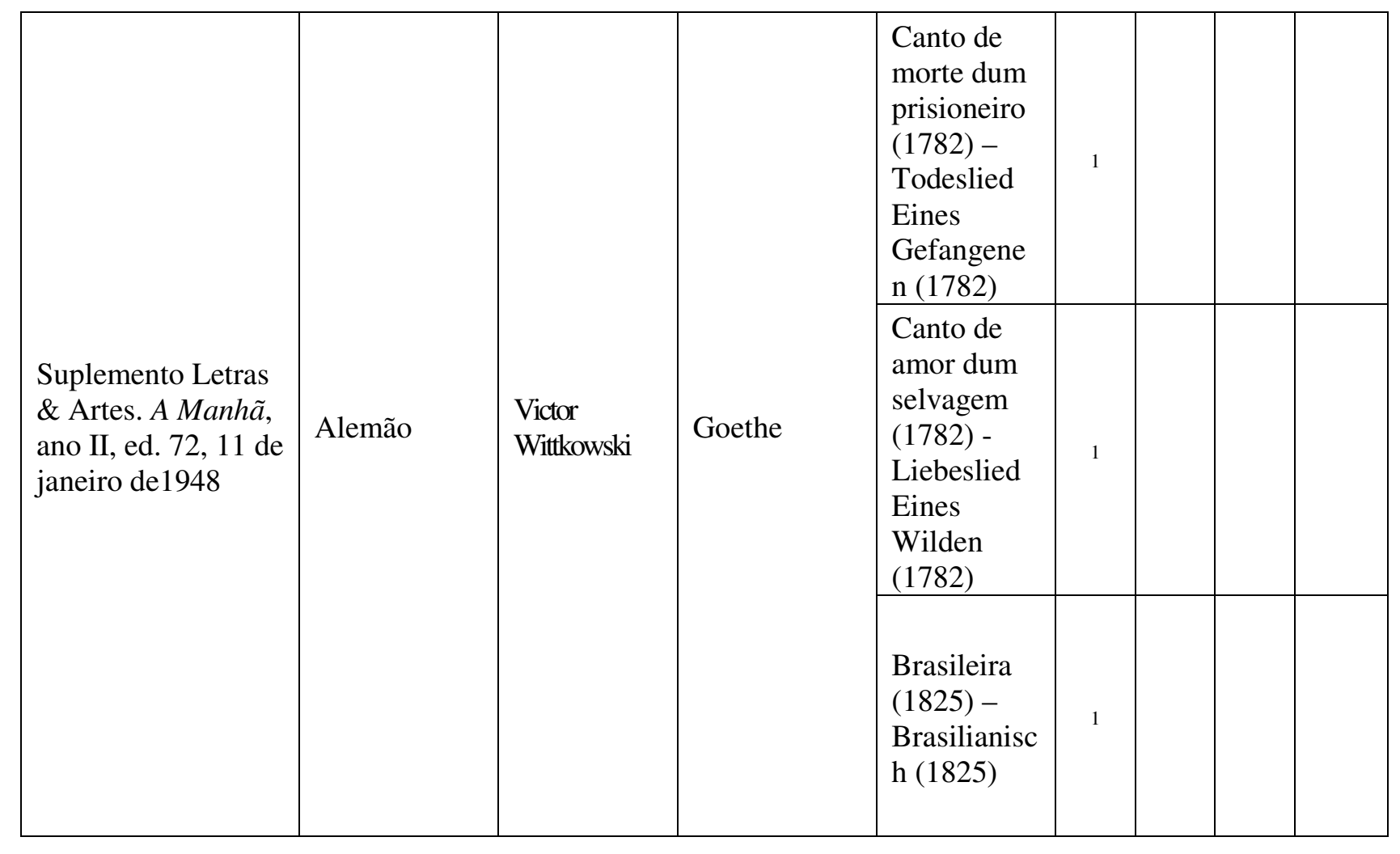

Revista Texto Poético | ISSN: 1808-5385 | Vol. 20 (1o sem-2016) - p. 115 


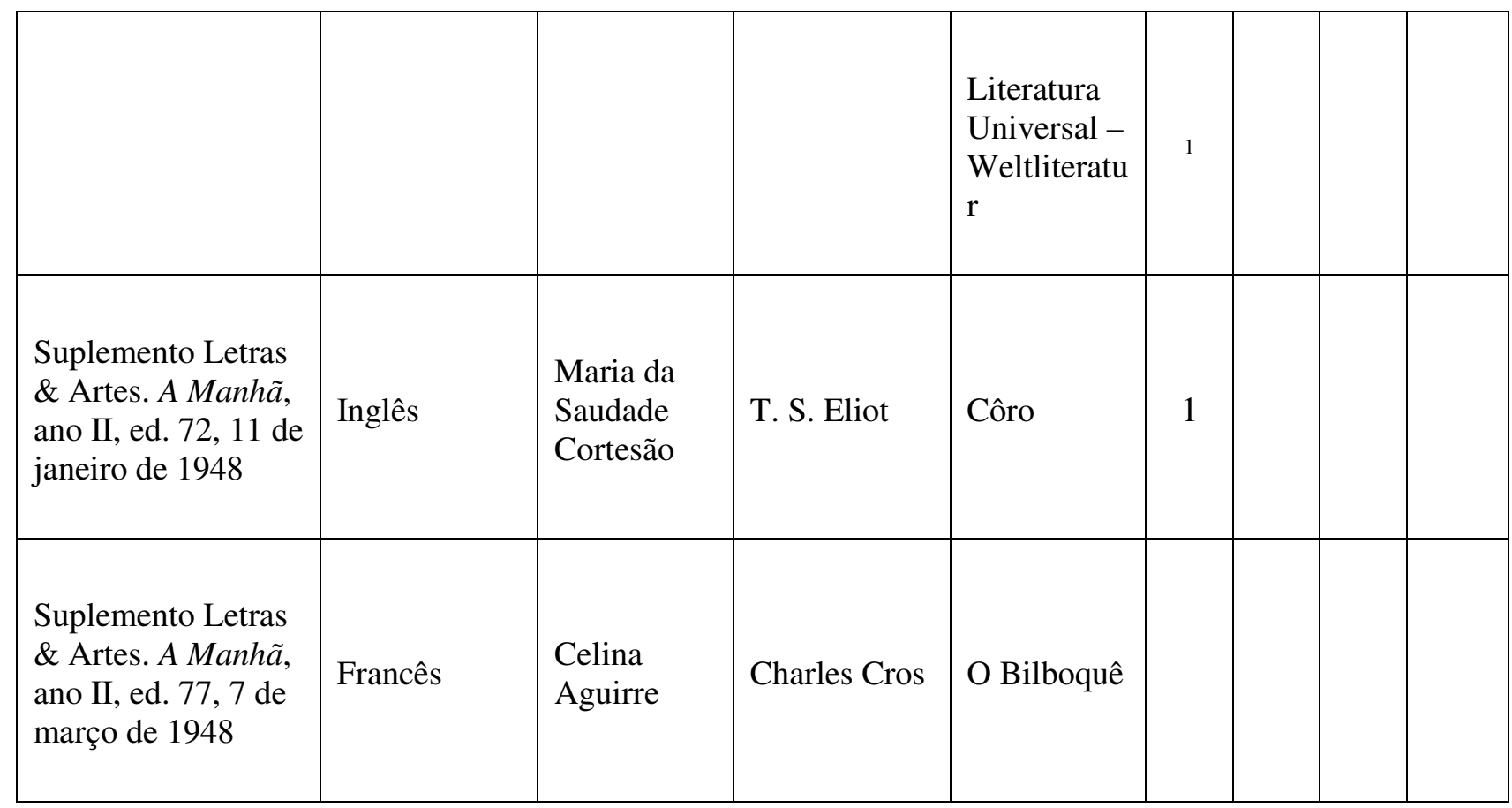

Revista Texto Poético | ISSN: 1808-5385 | Vol. 20 (1o sem-2016) - p. 116 


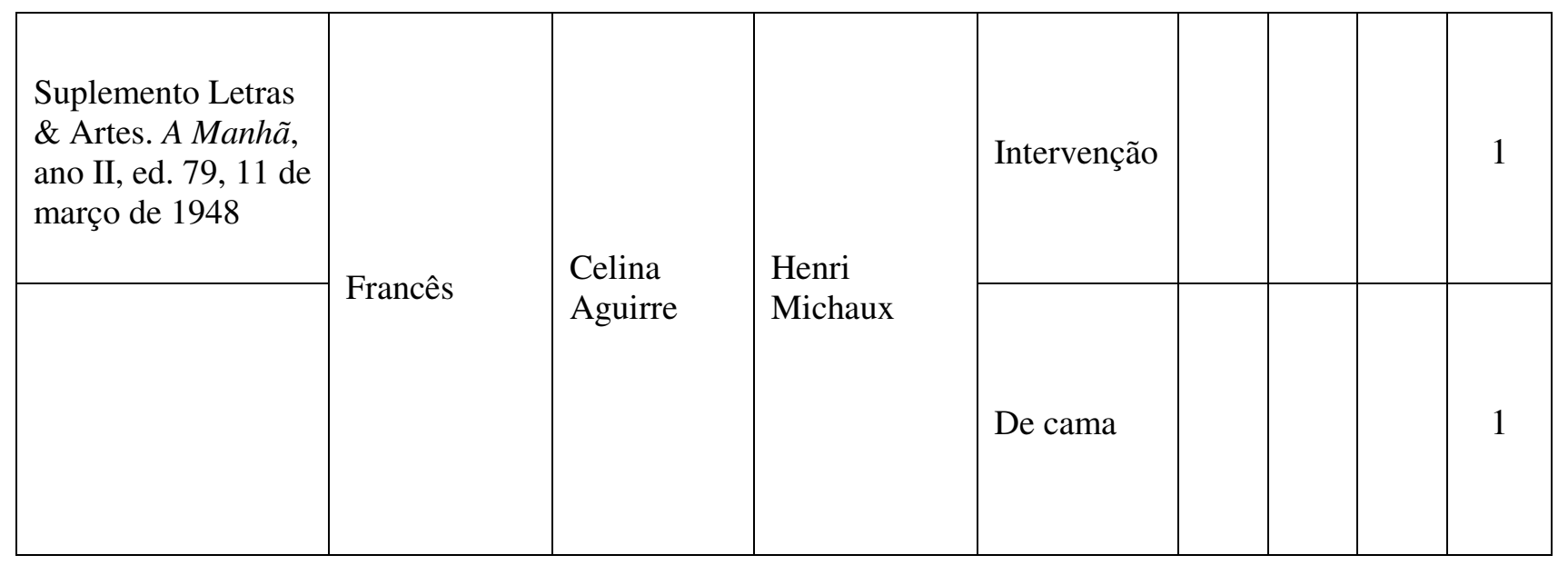




\section{9}

Quadro 4: esquematização das traduções publicadas no ano de 1949 no suplemento Letras \& Artes

\begin{tabular}{|c|c|c|c|c|c|c|c|c|}
\hline $\mathrm{ANO} / \mathbf{N}^{\circ}$ & 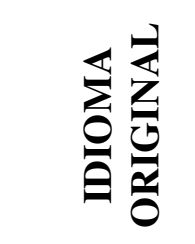 & 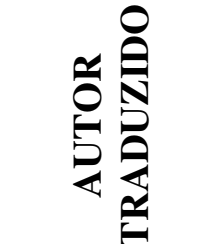 & 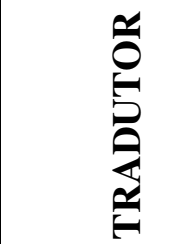 & 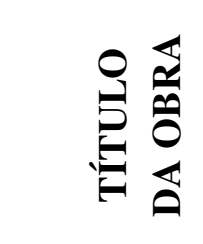 & $\sum_{i=1}^{\mathbb{1}}$ & 里 & 导 & 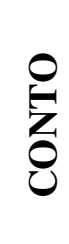 \\
\hline $\begin{array}{l}\text { Suplemento } \\
\text { Letras \& Artes. A } \\
\text { Manhãa, ano III, } \\
\text { ed. } 111,9 \text { de } \\
\text { janeiro de } 1949\end{array}$ & $\begin{array}{l}\text { Espanhol } \\
\text { (Argentina) }\end{array}$ & $\begin{array}{l}\text { Pedro Juan } \\
\text { Vignale }\end{array}$ & $\begin{array}{l}\text { Manuel } \\
\text { Bandeira }\end{array}$ & $\begin{array}{l}\text { Rosa } \\
\text { D'alva }\end{array}$ & 1 & & & \\
\hline
\end{tabular}




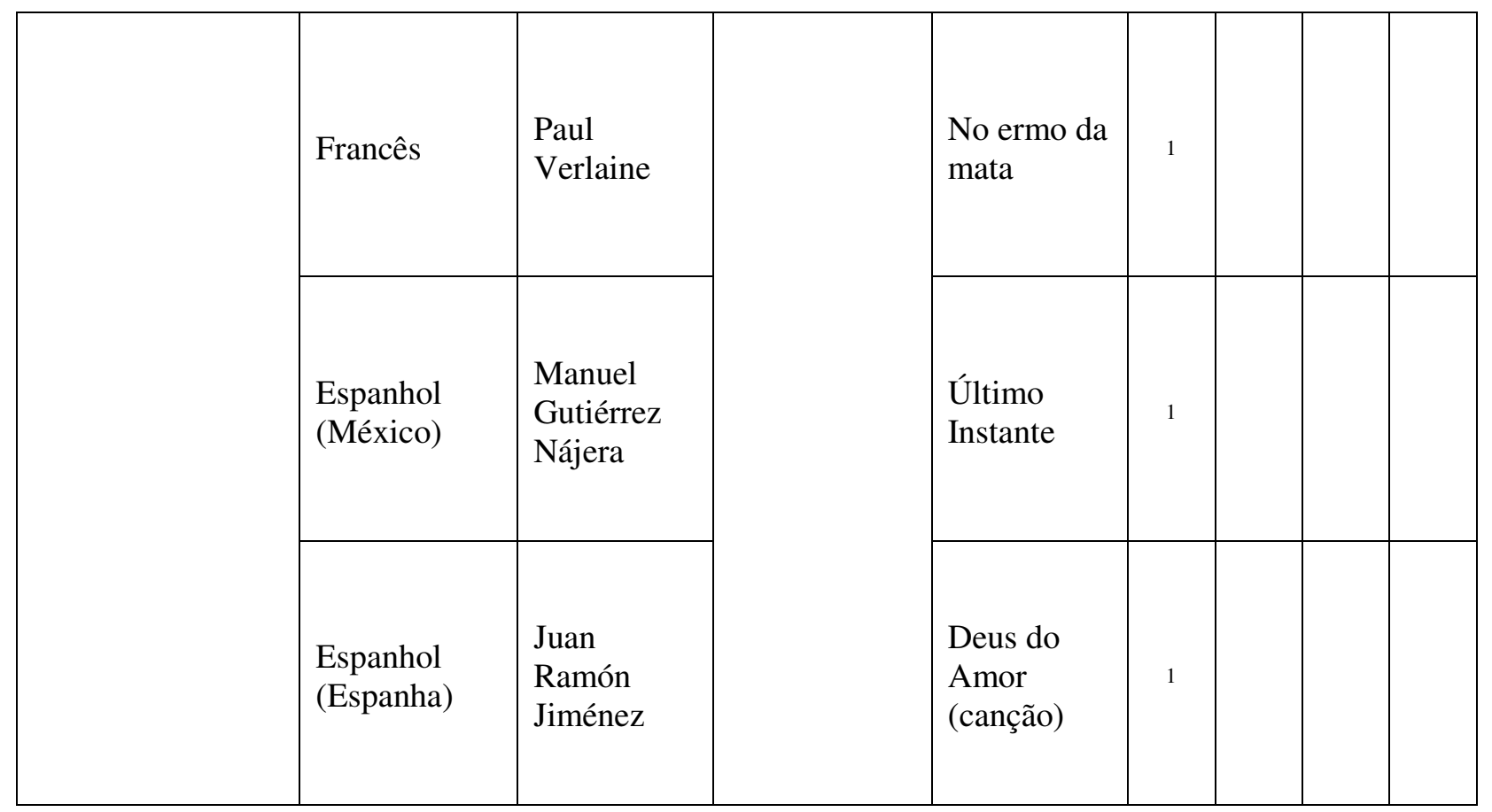

Revista Texto Poético | ISSN: 1808-5385 | Vol. 20 (1o sem-2016) - p. 119 


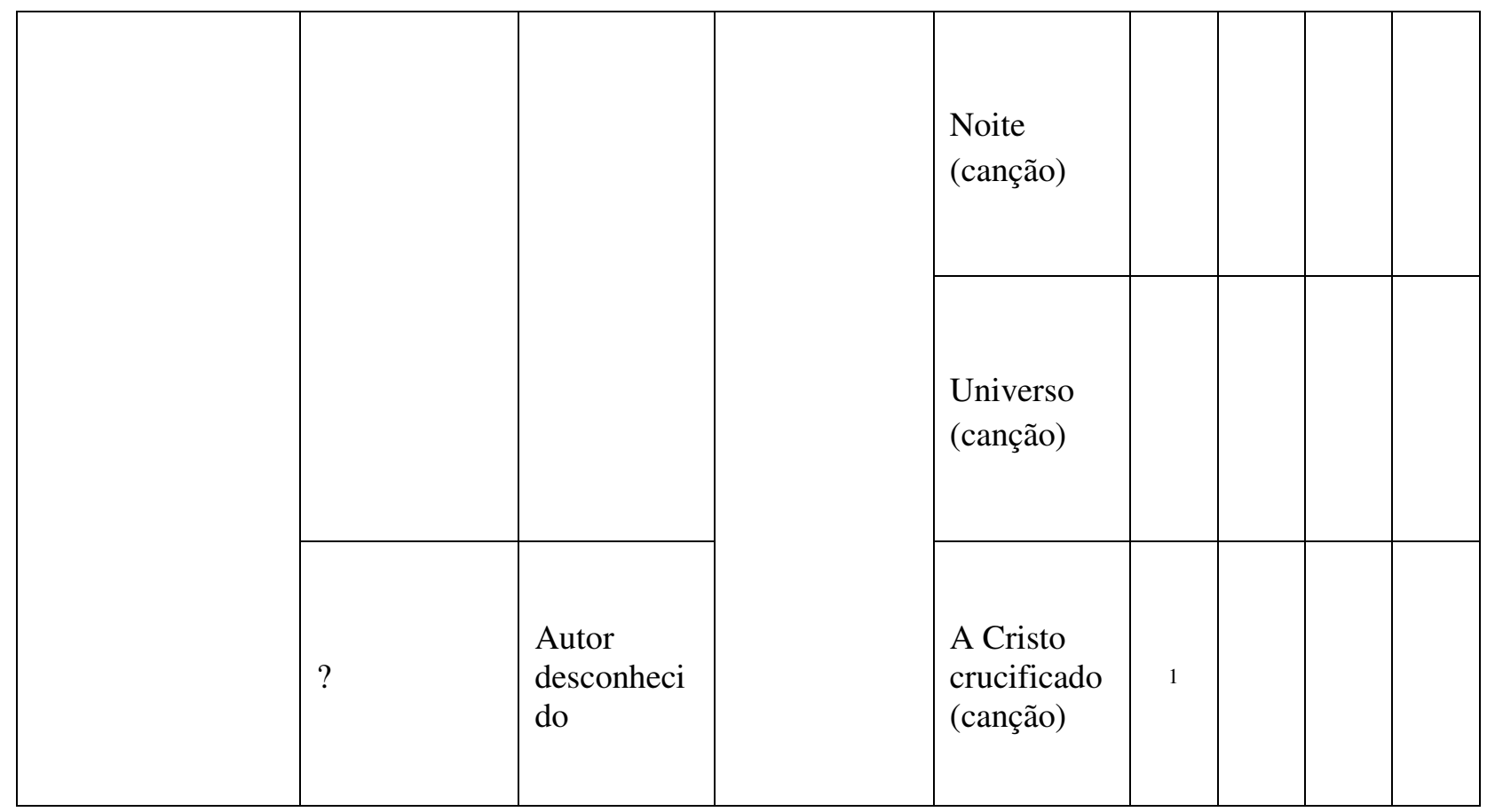

Revista Texto Poético | ISSN: 1808-5385 | Vol. 20 (1o sem-2016) - p. 120 


\begin{tabular}{|c|c|c|c|c|c|}
\hline & & $\begin{array}{l}\text { Elizabeth } \\
\text { Barret } \\
\text { Browning }\end{array}$ & & Soneto & \\
\hline & Alemão & $\begin{array}{l}\text { Rainer } \\
\text { Maria Rilke }\end{array}$ & $\begin{array}{l}\text { Paulo } \\
\text { Quintela }\end{array}$ & $\begin{array}{l}\text { Nascimento } \\
\text { de Vênus }\end{array}$ & \\
\hline $\begin{array}{l}\text { Suplemento } \\
\text { Letras \& Artes. A } \\
\text { Manhãa, ano III, } \\
\text { ed. } 113,23 \text { de } \\
\text { janeiro de } 1949\end{array}$ & $\begin{array}{l}\text { Espanhol } \\
\text { (Chile) }\end{array}$ & $\begin{array}{l}\text { Gabriela } \\
\text { Mistral }\end{array}$ & $\begin{array}{l}\text { Manuel } \\
\text { Bandeira }\end{array}$ & $\begin{array}{l}\text { O pensador } \\
\text { de Rodin }\end{array}$ & 1 \\
\hline
\end{tabular}




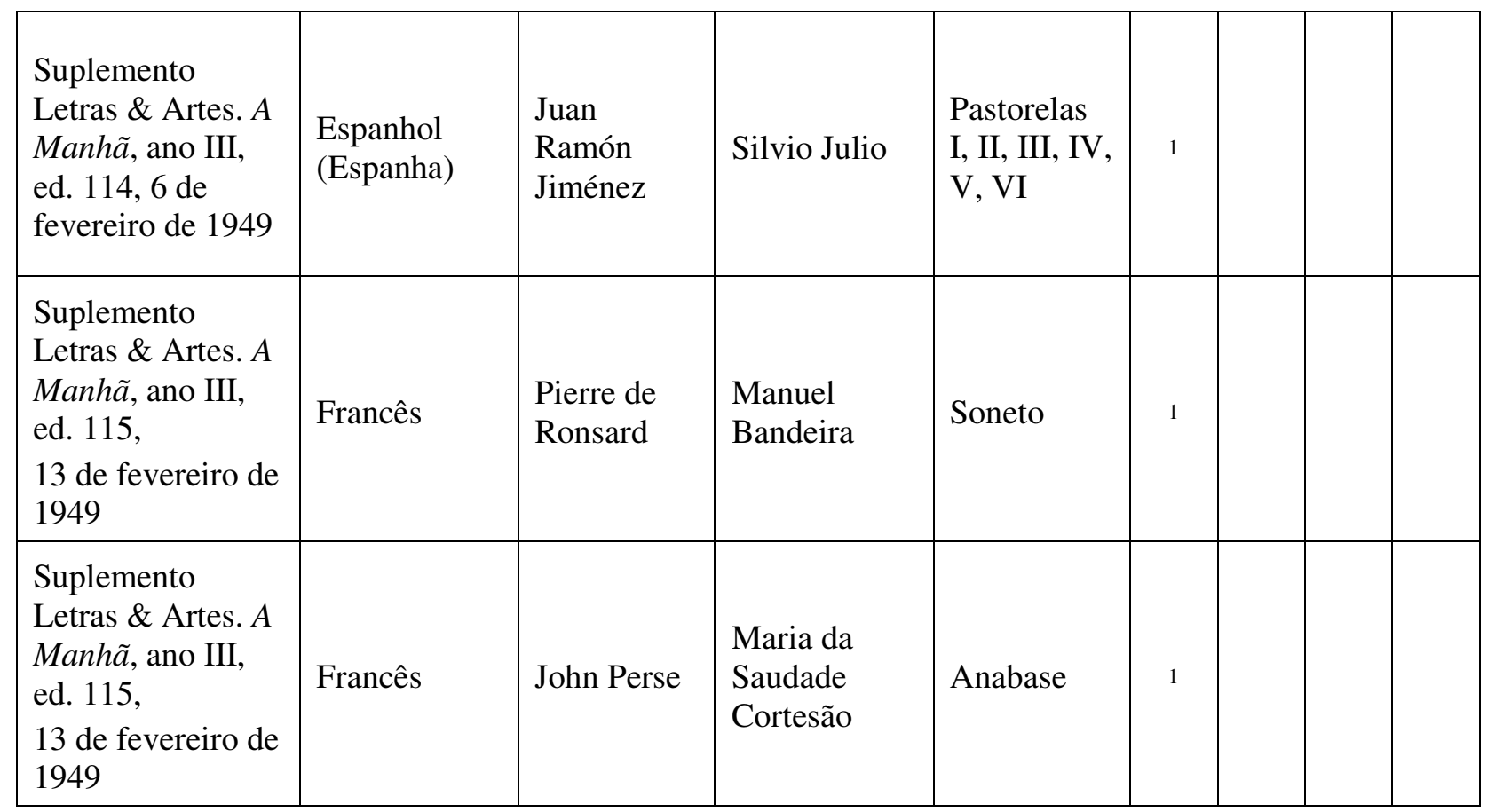




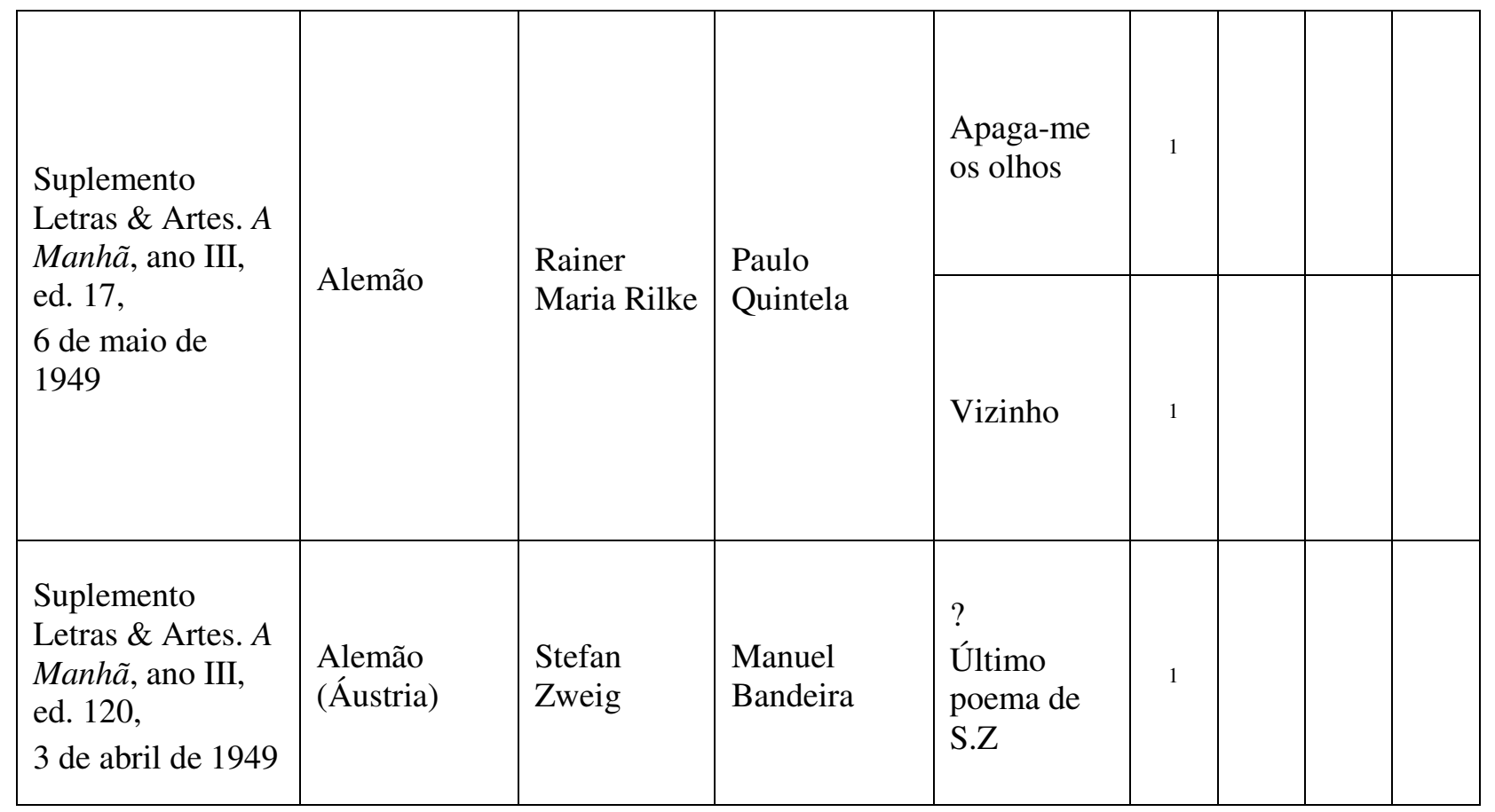

Revista Texto Poético | ISSN: 1808-5385 | Vol. 20 (1o sem-2016) - p. 123 


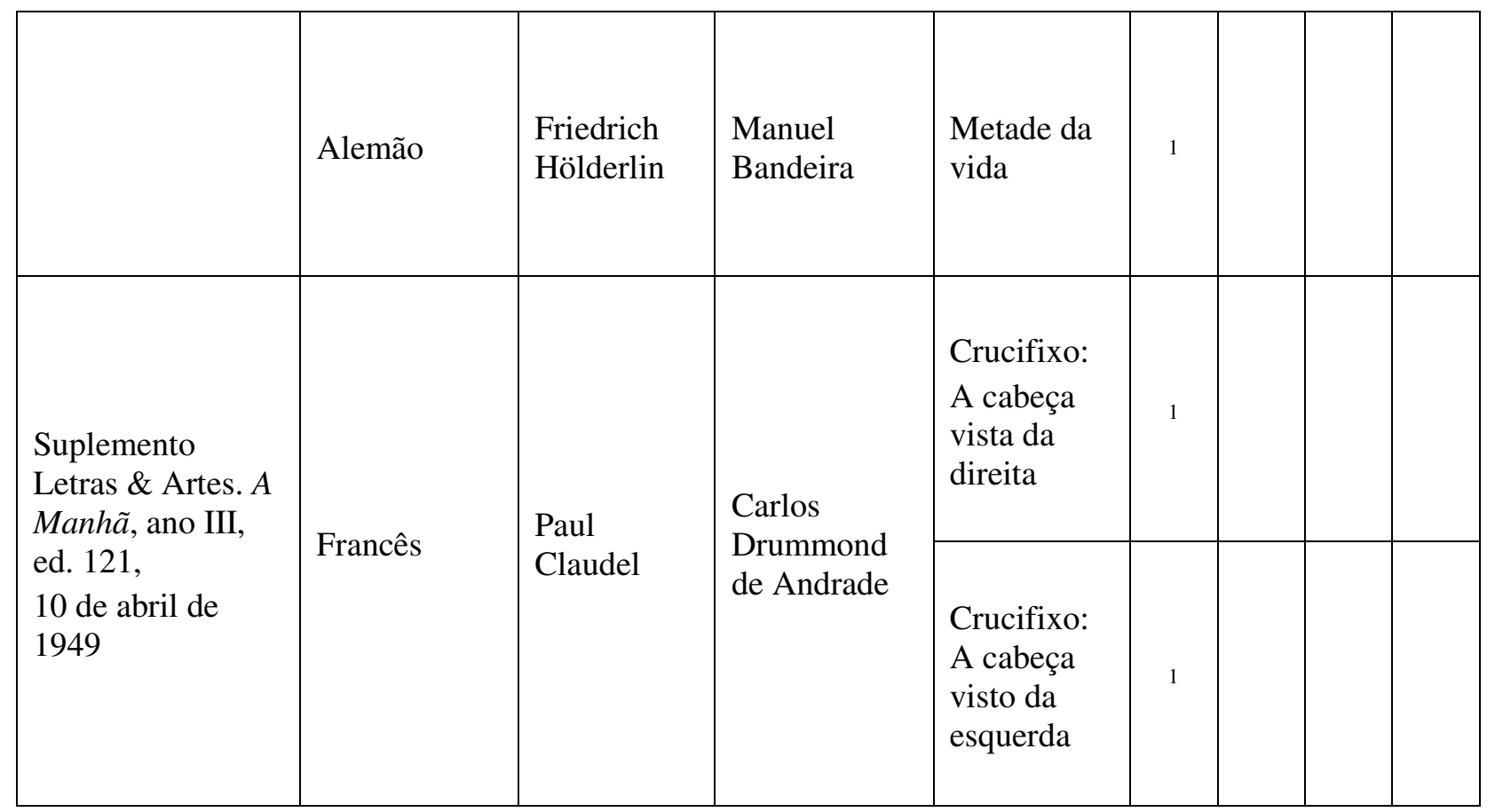

Revista Texto Poético | ISSN: 1808-5385 | Vol. 20 (1o sem-2016) - p. 124 


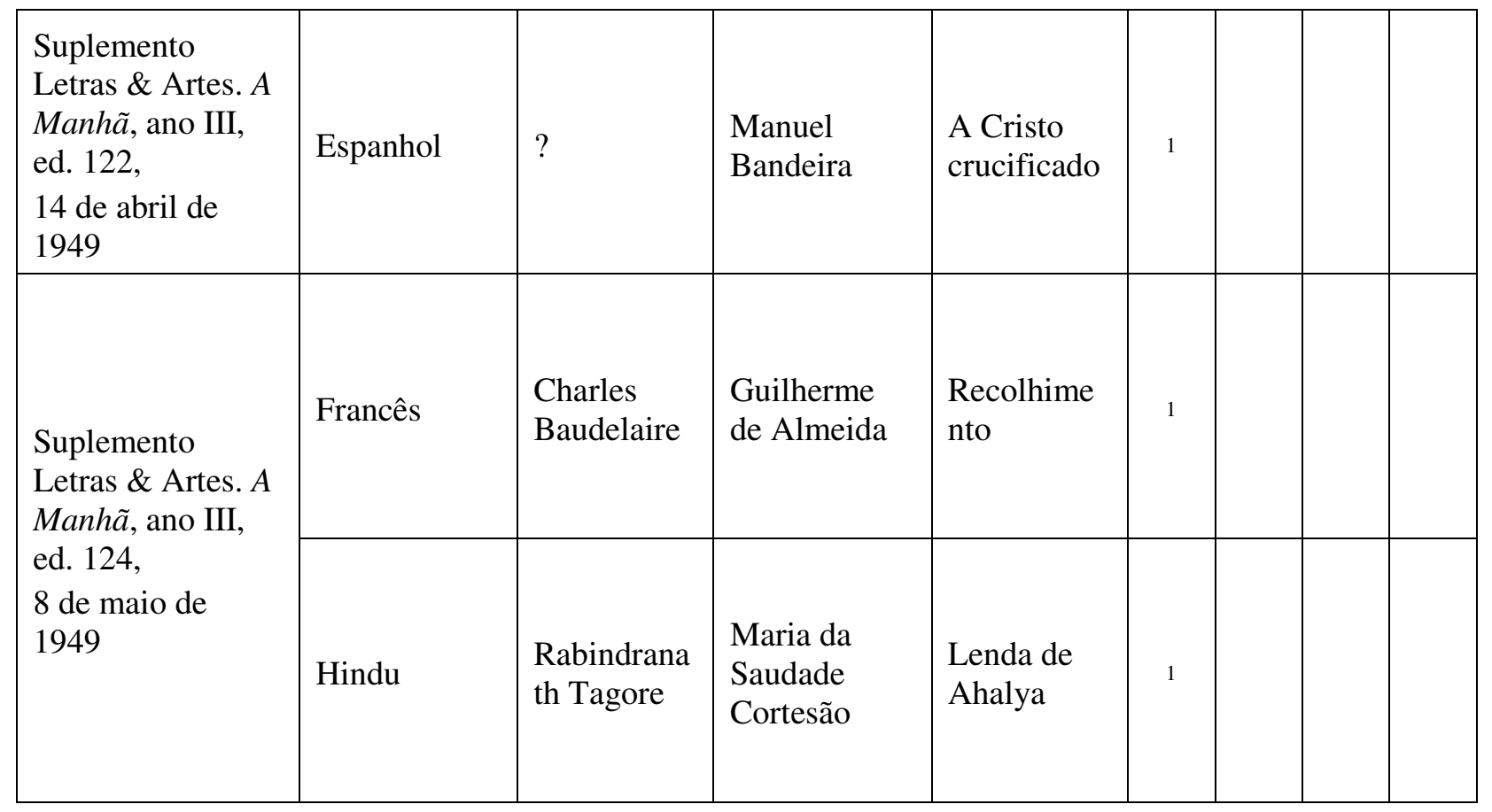

Revista Texto Poético | ISSN: 1808-5385 | Vol. 20 (1o sem-2016) - p. 125 


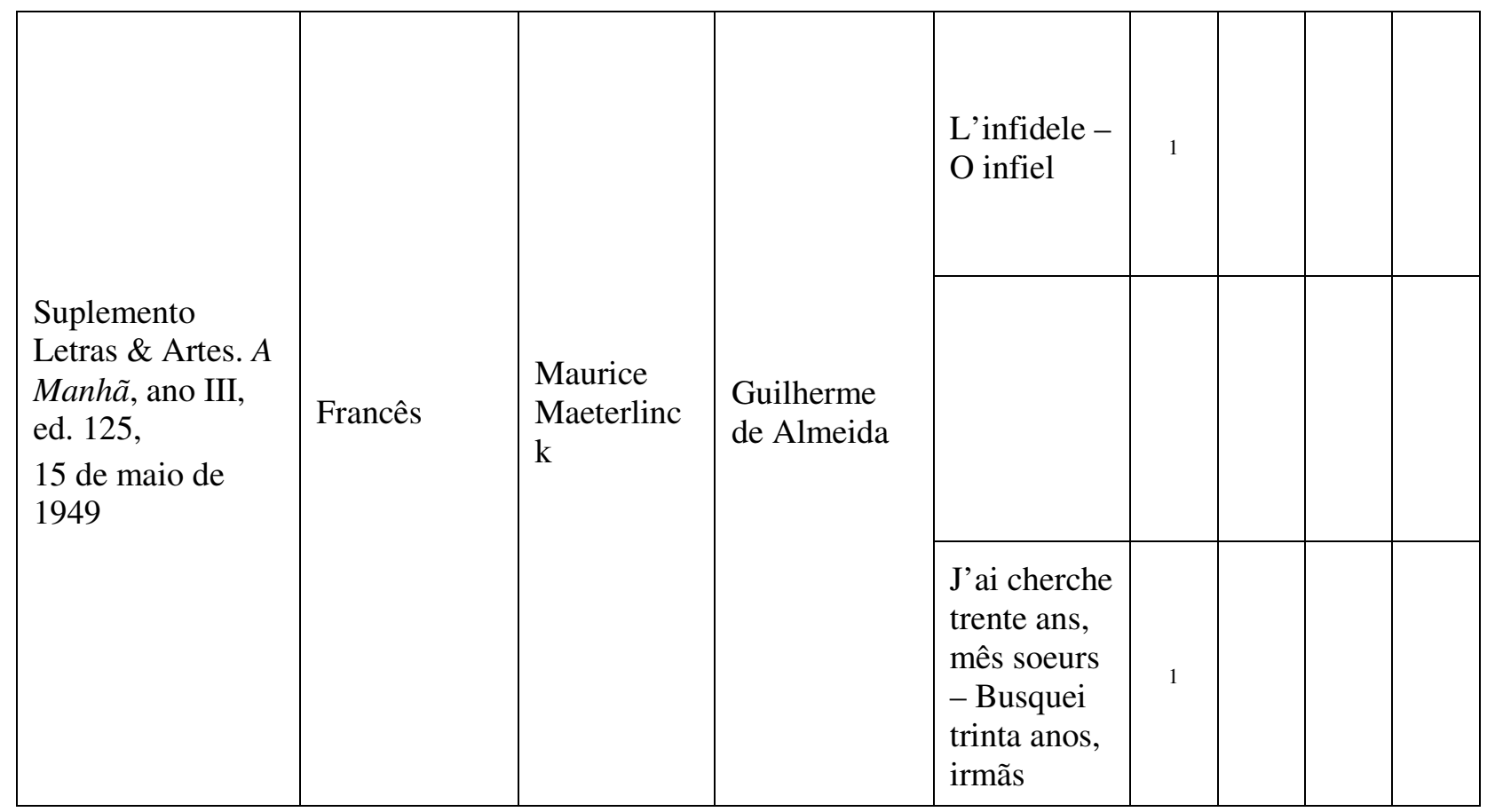

Revista Texto Poético | ISSN: 1808-5385 | Vol. 20 (1o sem-2016) - p. 126 


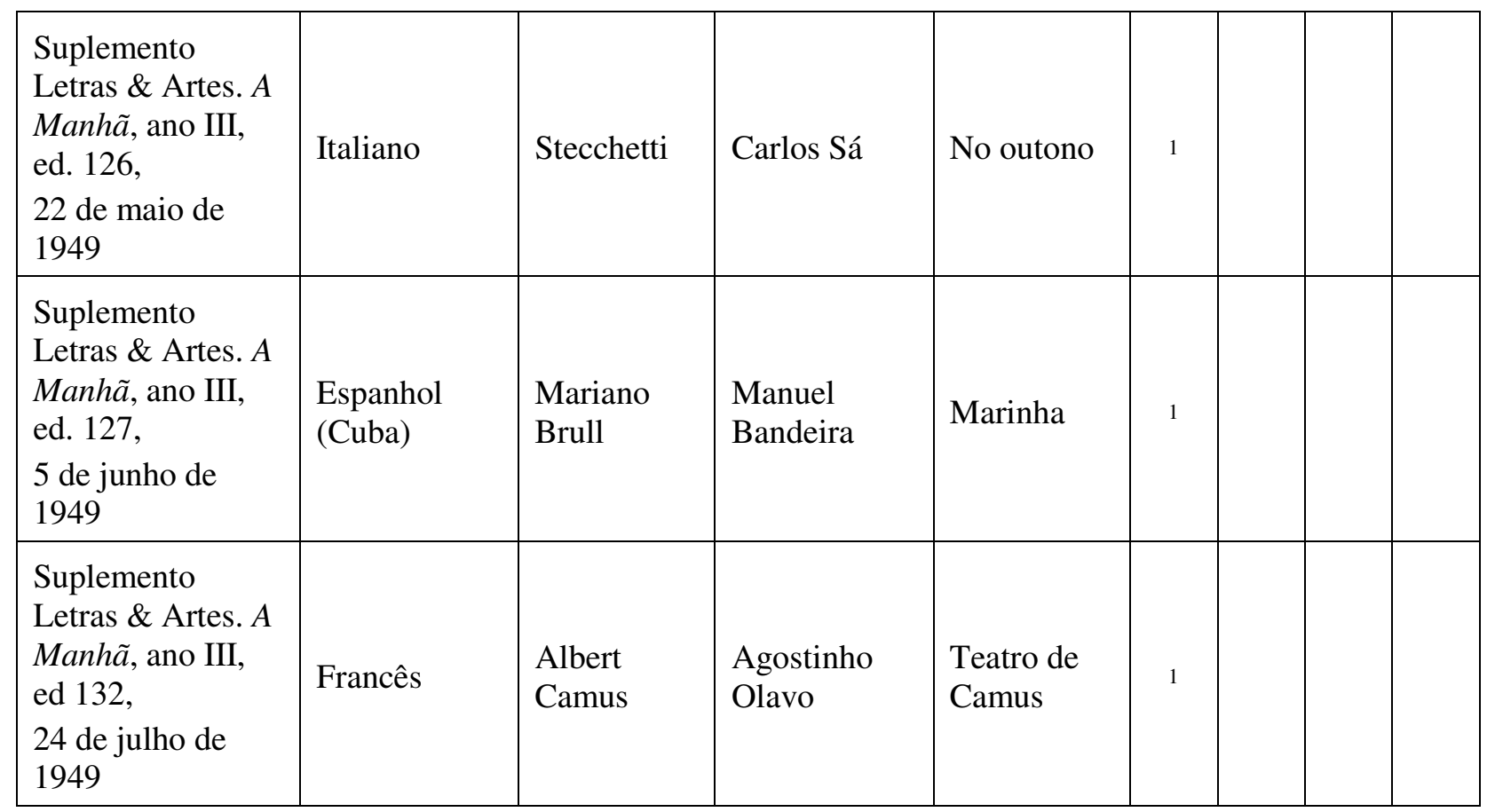

Revista Texto Poético | ISSN: 1808-5385 | Vol. 20 (1o sem-2016) - p. 127 


\begin{tabular}{|c|c|c|c|c|c|c|c|}
\hline & Francês & Claude Roy & $\begin{array}{l}\text { Claudio } \\
\text { Tavares } \\
\text { Barbosa }\end{array}$ & $\begin{array}{l}\text { Aventuras } \\
\text { de um Bom } \\
\text { Rapaz no } \\
\text { país dos } \\
\text { Grandes } \\
\text { Homens }\end{array}$ & & & 1 \\
\hline $\begin{array}{l}\text { Suplemento } \\
\text { Letras \& Artes. A } \\
\text { Manhã, ano III, } \\
\text { ed. } 132 \text {, } \\
24 \text { de julho de } \\
1949\end{array}$ & Francês & $\begin{array}{l}\text { Albert } \\
\text { Camus }\end{array}$ & $\begin{array}{l}\text { Maria da } \\
\text { Saudade } \\
\text { Cortesão }\end{array}$ & $\begin{array}{l}\text { Um } \\
\text { moralista } \\
\text { da revolta: } \\
\text { Chamfort }\end{array}$ & & 1 & \\
\hline $\begin{array}{l}\text { Suplemento } \\
\text { Letras \& Artes. A } \\
\text { Manhã ano III, } \\
\text { ed. } 135, \\
28 \text { de agosto de } \\
1949\end{array}$ & Alemão & Goethe & $\begin{array}{l}\text { Leony de } \\
\text { Oliveira } \\
\text { Machado }\end{array}$ & $\begin{array}{l}\text { Elegia de } \\
\text { Marienbad }\end{array}$ & 1 & & \\
\hline
\end{tabular}

Revista Texto Poético | ISSN: 1808-5385 | Vol. 20 (1o sem-2016) - p. 128 


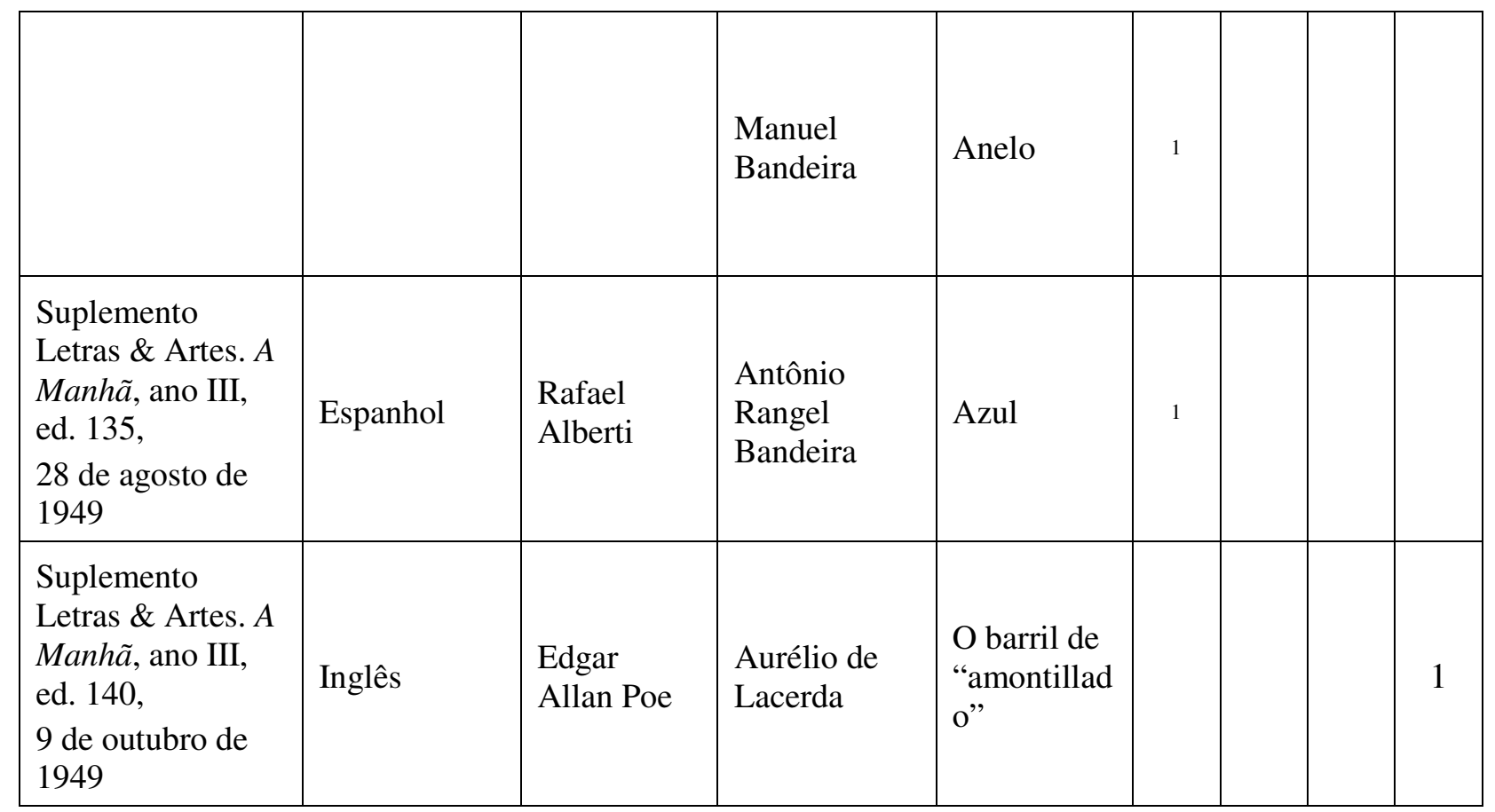

Revista Texto Poético | ISSN: 1808-5385 | Vol. 20 (1o sem-2016) - p. 129 


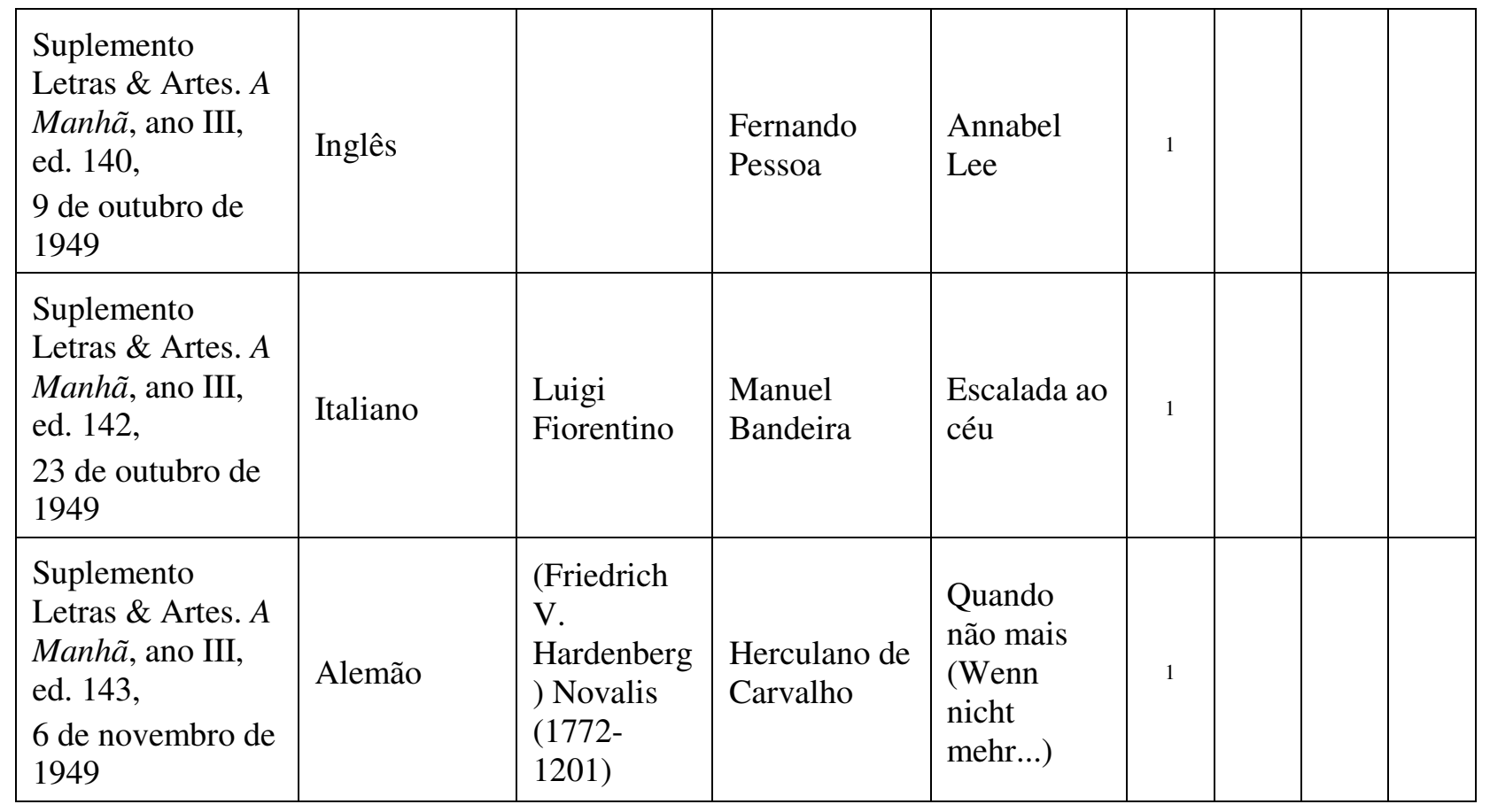

Revista Texto Poético | ISSN: 1808-5385 | Vol. 20 (1o sem-2016) - p. 130 


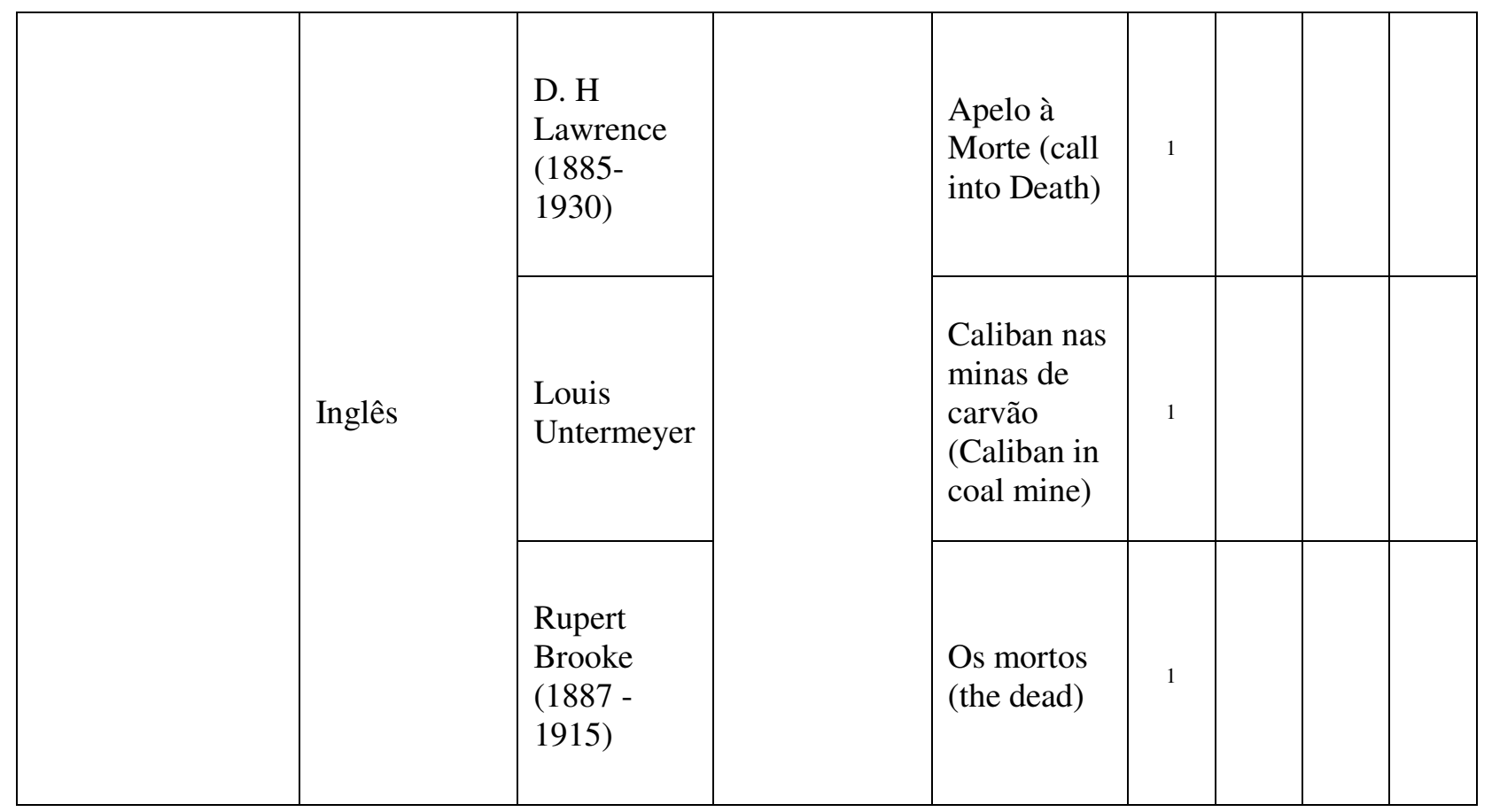

Revista Texto Poético | ISSN: 1808-5385 | Vol. 20 (1o sem-2016) - p. 131 


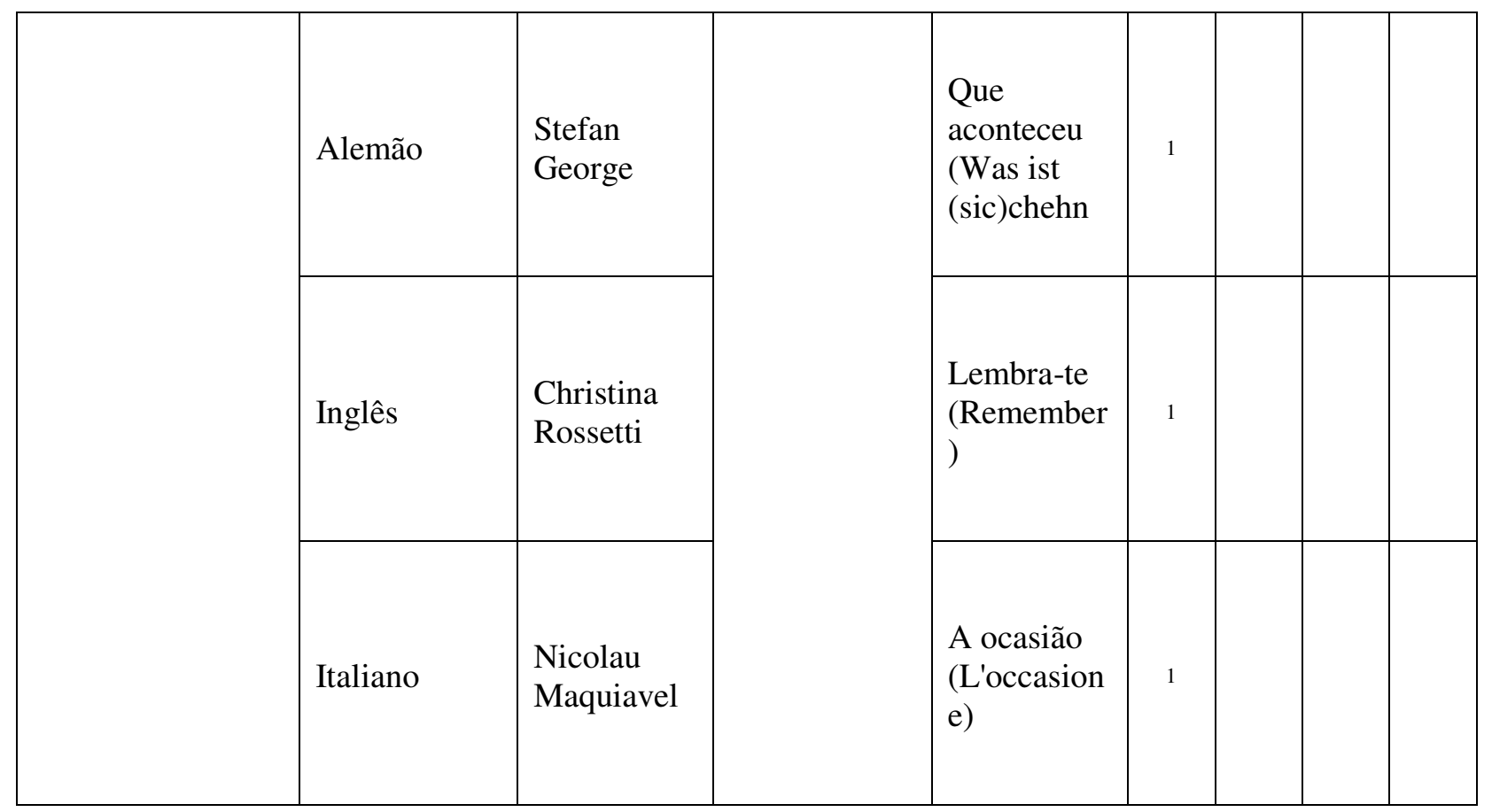

Revista Texto Poético | ISSN: 1808-5385 | Vol. 20 (1o sem-2016) - p. 132 


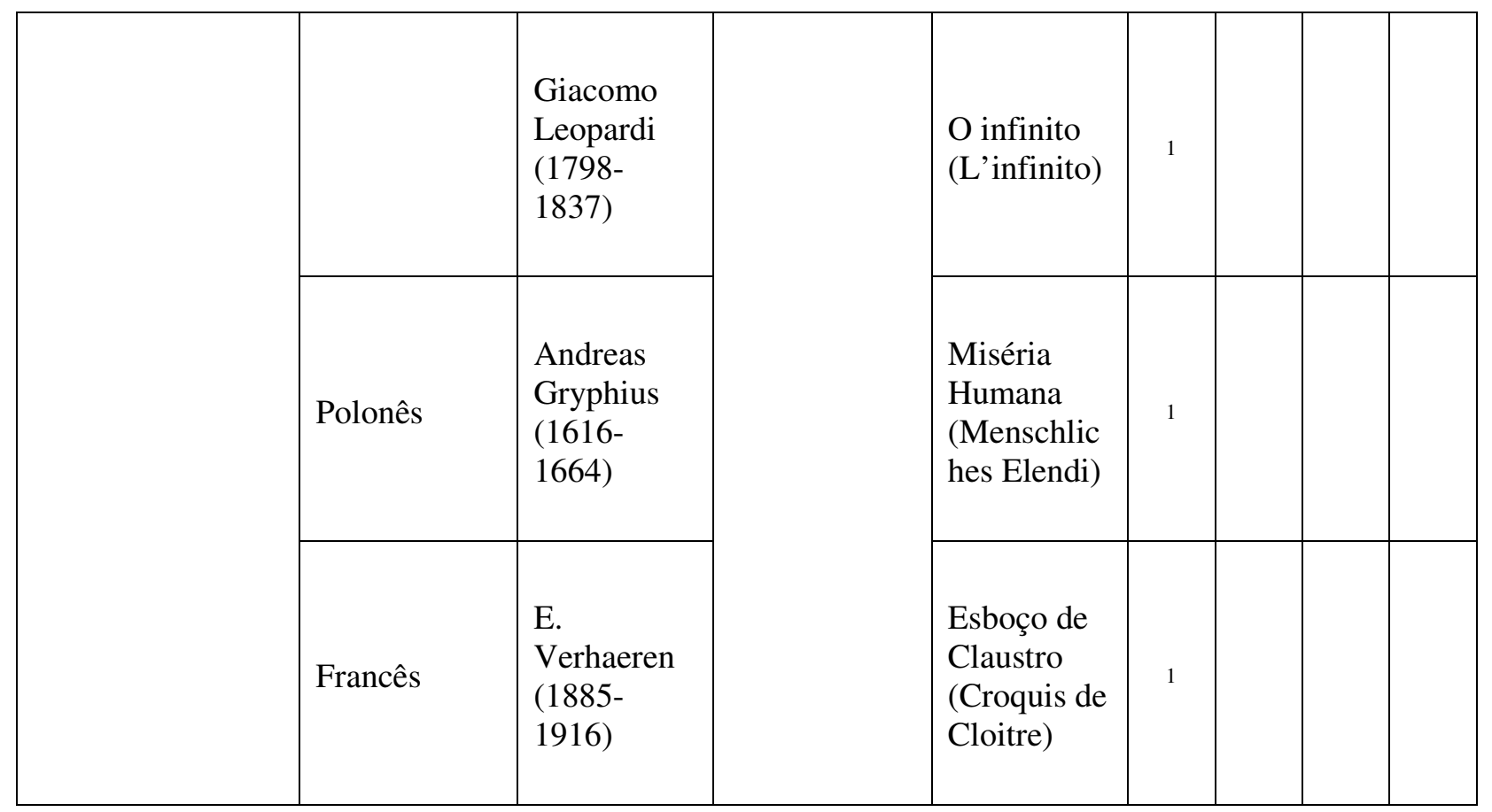

Revista Texto Poético | ISSN: 1808-5385 | Vol. 20 (1o sem-2016) - p. 133 


\begin{tabular}{|c|c|c|c|c|c|}
\hline & Francês & $\begin{array}{l}\text { Albert } \\
\text { Samain } \\
(1852- \\
1919)\end{array}$ & & $\begin{array}{l}\text { A esfinge } \\
\text { (Le Sphinx) }\end{array}$ & 1 \\
\hline $\begin{array}{l}\text { Suplemento } \\
\text { Letras \& Artes. A } \\
\text { Manhã, ano III, } \\
\text { ed. } 143, \\
6 \text { de novembro de } \\
1949\end{array}$ & Inglês & $\begin{array}{l}\text { Edgar } \\
\text { Allan Poe }\end{array}$ & $\begin{array}{l}\text { Milton } \\
\text { Amado }\end{array}$ & $\begin{array}{l}\text { A Alguém } \\
\text { no Paraíso }\end{array}$ & \\
\hline $\begin{array}{l}\text { Suplemento } \\
\text { Letras \& Artes. A } \\
\text { Manhã, ano III, } \\
\text { ed. } 145, \\
20 \text { de novembro } \\
\text { de } 1949\end{array}$ & Alemão & $\begin{array}{l}\text { Friedrich } \\
\text { Hölderlin }\end{array}$ & $\begin{array}{l}\text { Herculano de } \\
\text { Carvalho }\end{array}$ & A Pátria & 1 \\
\hline
\end{tabular}

Revista Texto Poético | ISSN: 1808-5385 | Vol. 20 (1o sem-2016) - p. 134 


\begin{tabular}{|l|l|l|l|l|l|l|l|l|}
\hline & & & $\begin{array}{l}\text { Manuel } \\
\text { Bandeira }\end{array}$ & $\begin{array}{l}\text { Outrora e } \\
\text { Hoje }\end{array}$ & 1 & & \\
\hline $\begin{array}{l}\text { Suplemento } \\
\text { Letras \& Artes. } A \\
\begin{array}{l}\text { Manhã ano III, } \\
\text { ed. } 146, \\
4 \text { de dezembro de } \\
1949\end{array}\end{array}$ & Português & Camões & $\begin{array}{l}\text { Fernando } \\
\text { Pessoa }\end{array}$ & $\begin{array}{l}\text { Soneto } \\
\text { "Minha } \\
\text { alma gentil, } \\
\text { que te } \\
\text { partiste" }\end{array}$ & 1 & & \\
\hline
\end{tabular}


1950

Quadro 5: esquematização das traduções publicadas no ano de 1950 no suplemento Letras \& Artes

\begin{tabular}{|c|c|c|c|c|c|c|c|}
\hline $\mathrm{ANO} / \mathrm{N}^{\circ}$ & 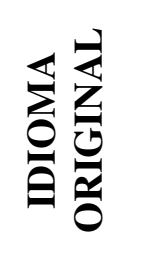 & 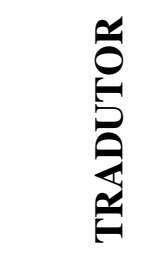 & 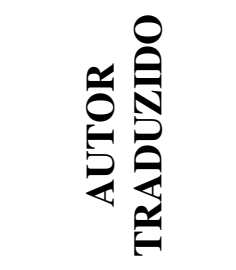 & 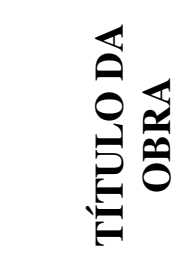 & $\sum_{\substack{1 \\
0}}^{\$ 1}$ & 总 & 苍 \\
\hline $\begin{array}{l}\text { Suplemento } \\
\text { Letras \& Artes. } \\
\text { A Manhãa, ano } \\
\text { IV, ed. } 167 \text {, } \\
11 \text { de junho de } \\
1950\end{array}$ & Alemão & $\begin{array}{l}\text { Paulo } \\
\text { Quintela }\end{array}$ & $\begin{array}{l}\text { Rainer Maria } \\
\text { Rilke }\end{array}$ & O Licorne & 1 & & \\
\hline
\end{tabular}




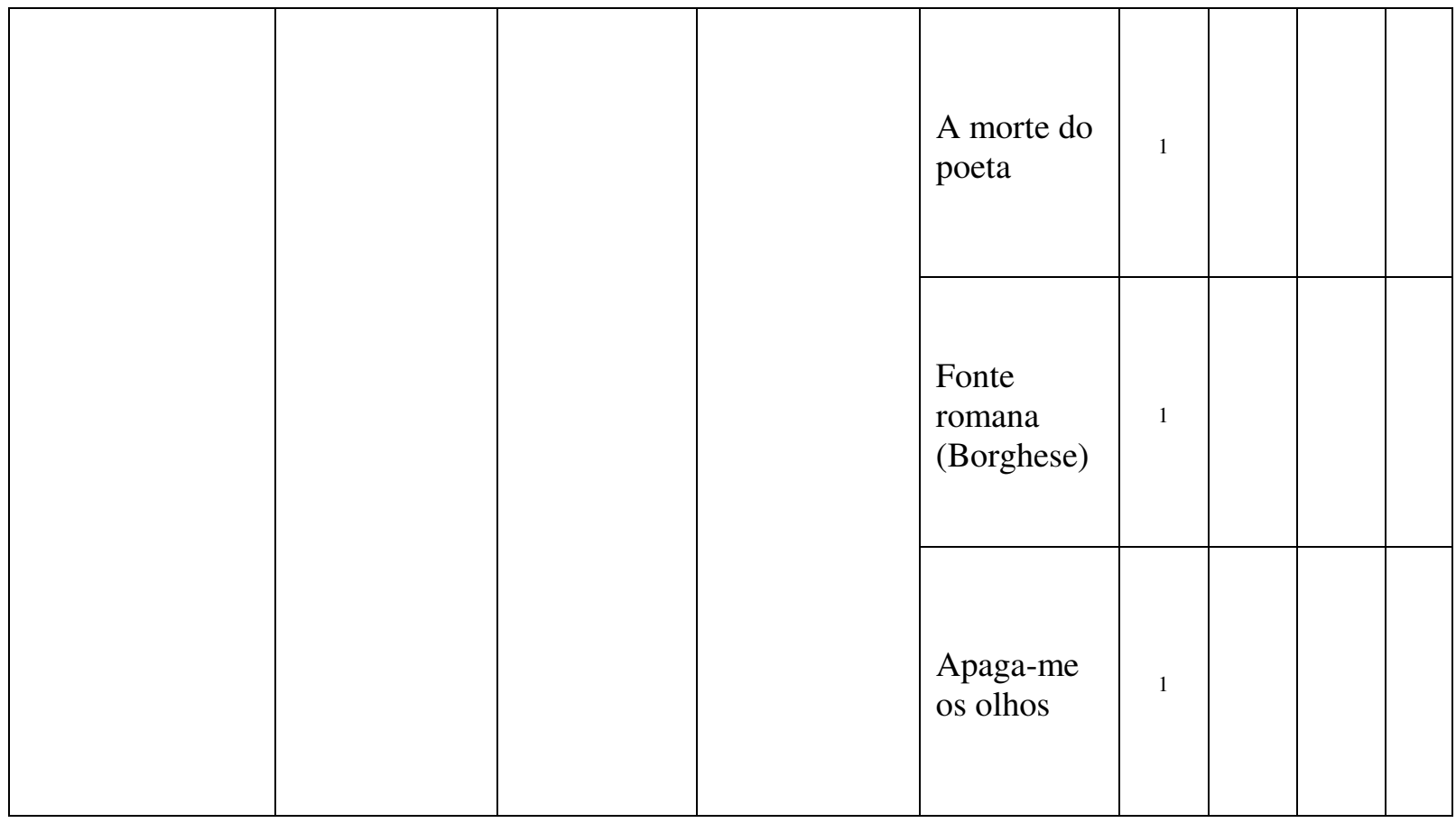

Revista Texto Poético | ISSN: 1808-5385 | Vol. 20 (1o sem-2016) - p. 137 


\begin{tabular}{|c|c|c|c|c|c|}
\hline & & & & Hora grave & 1 \\
\hline $\begin{array}{l}\text { Suplemento } \\
\text { Letras \& Artes. } \\
\text { A Manhã, ano } \\
\text { IV, ed. } 155 \text {, } \\
19 \text { de fevereiro } \\
\text { de } 1950\end{array}$ & Francês & $\begin{array}{l}\text { Onestaldo } \\
\text { Pennafort }\end{array}$ & $\begin{array}{l}\text { Paul } \\
\text { Verlaine }\end{array}$ & Colombina & 1 \\
\hline $\begin{array}{l}\text { Suplemento } \\
\text { Letras \& Artes. } \\
\text { A Manhã ano } \\
\text { IV, ed. } 167, \\
1^{\circ} \text { janeiro de } \\
1950\end{array}$ & Francês & $\begin{array}{l}\text { Darcy } \\
\text { Damasceno }\end{array}$ & Paul Valéry & $\begin{array}{l}\text { Cemitério } \\
\text { marinho }\end{array}$ & 1 \\
\hline
\end{tabular}

Revista Texto Poético | ISSN: 1808-5385 | Vol. 20 (1o sem-2016) - p. 138 


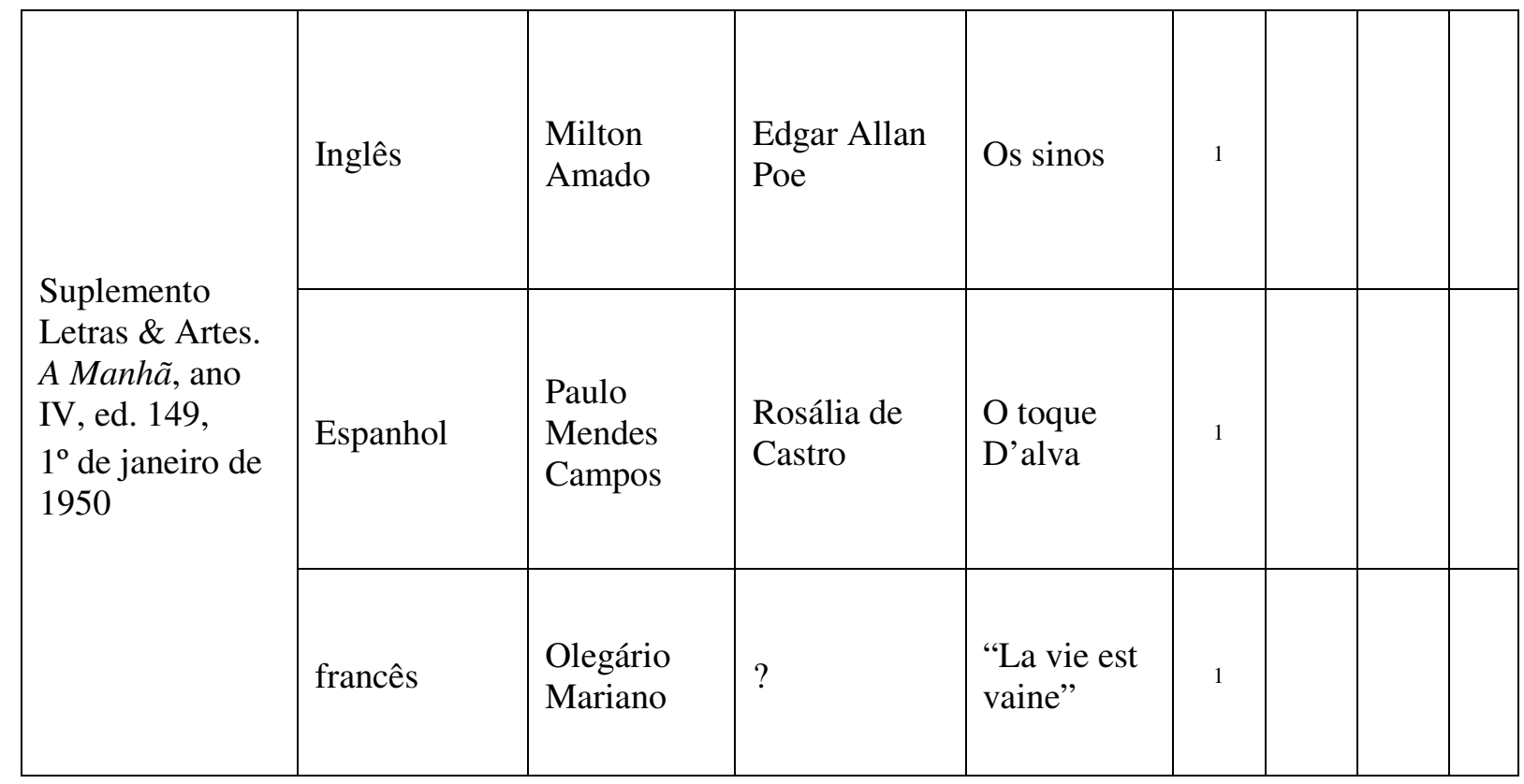

Revista Texto Poético | ISSN: 1808-5385 | Vol. 20 (1o sem-2016) - p. 139 


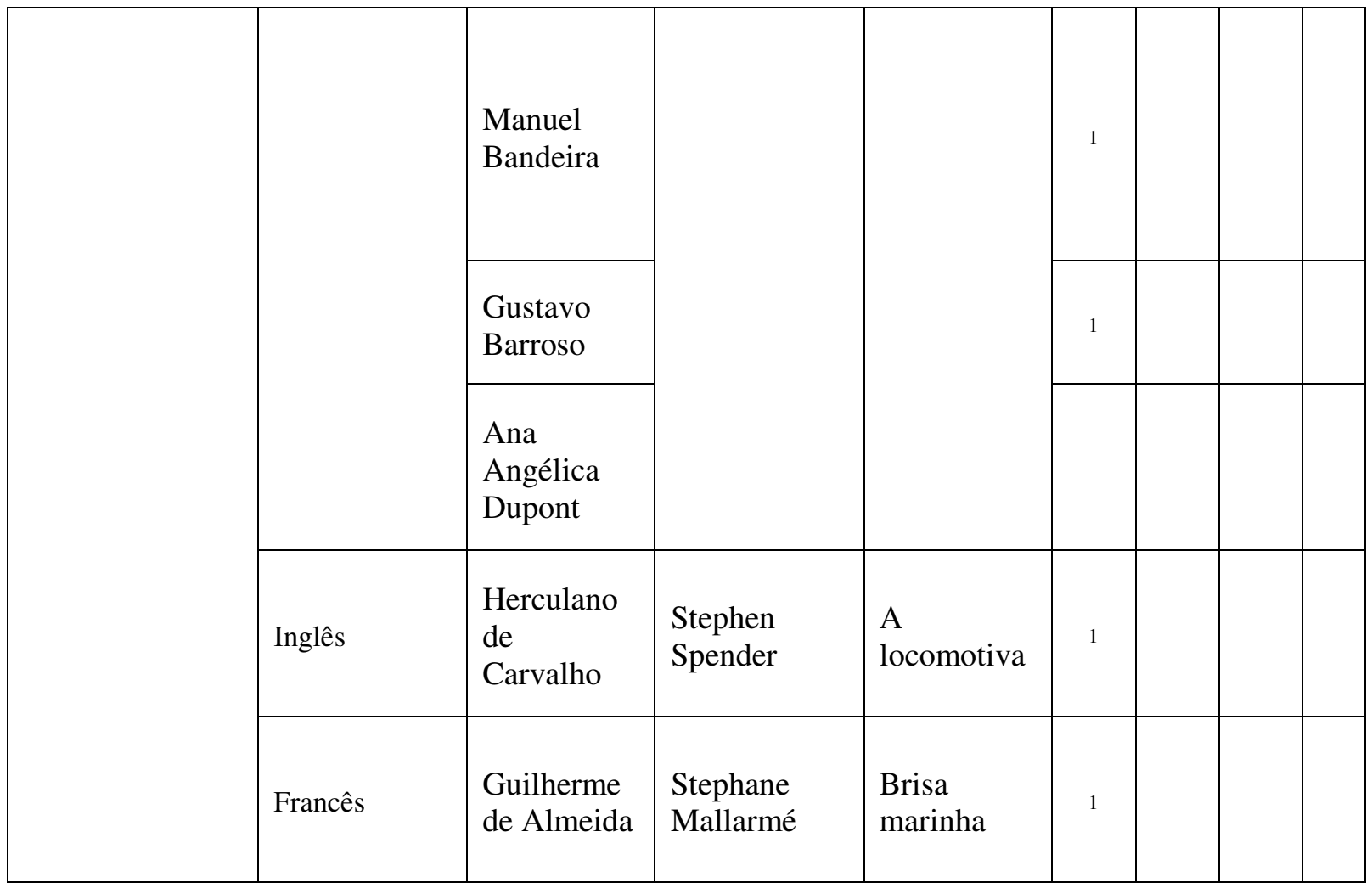

Revista Texto Poético | ISSN: 1808-5385 | Vol. 20 (1o sem-2016) - p. 140 


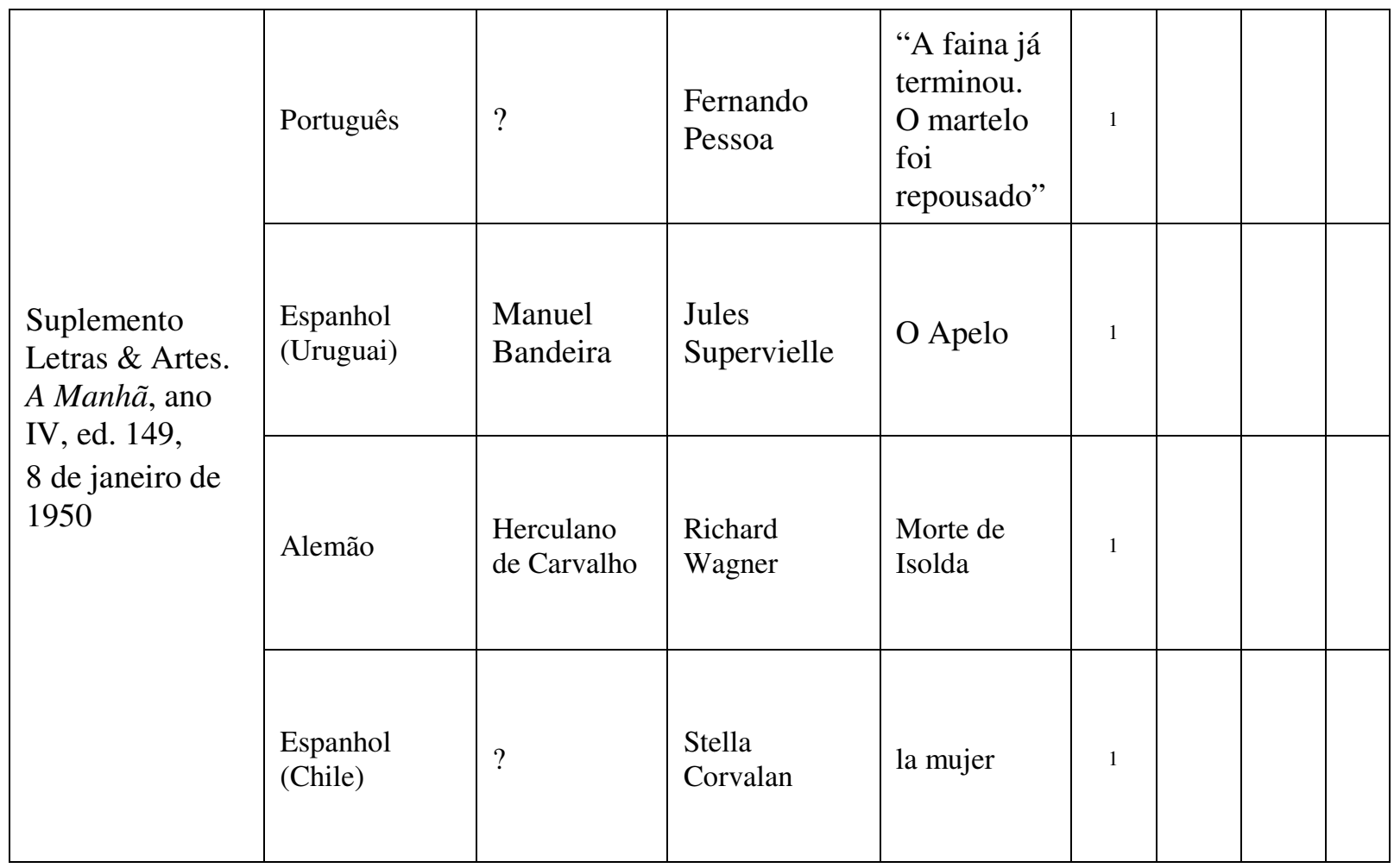

Revista Texto Poético | ISSN: 1808-5385 | Vol. 20 (1o sem-2016) - p. 141 


\begin{tabular}{|c|c|c|c|c|c|}
\hline & & & & La madre & 1 \\
\hline & & & & La artista & 1 \\
\hline $\begin{array}{l}\text { Suplemento } \\
\text { Letras \& Artes. } \\
\text { A Manhã, ano } \\
\text { IV, ed. } 151 \text {, } \\
15 \text { de janeiro de } \\
1950\end{array}$ & Francês & $\begin{array}{l}\text { Olegário } \\
\text { Mariano }\end{array}$ & $\begin{array}{l}\text { Miguel } \\
\text { Zamacois }\end{array}$ & O Zéfiro & 1 \\
\hline $\begin{array}{l}\text { Suplemento } \\
\text { Letras \& Artes. } \\
\text { A Manhã, ano } \\
\text { IV, ed. } 151 \text {, } \\
22 \text { de janeiro de } \\
1950\end{array}$ & Francês & $\begin{array}{l}\text { Hernani T. } \\
\text { Sant'Ana }\end{array}$ & ? & $\begin{array}{l}\text { "La vie est } \\
\text { vaine" }\end{array}$ & 1 \\
\hline
\end{tabular}

Revista Texto Poético | ISSN: 1808-5385 | Vol. 20 (1o sem-2016) - p. 142 


\begin{tabular}{|c|c|c|c|c|c|c|}
\hline $\begin{array}{l}\text { Suplemento } \\
\text { Letras \& Artes. } \\
\text { A Manhã, ano }\end{array}$ & Inglês & $\begin{array}{l}\text { Raimundo } \\
\text { Magalhães } \\
\text { Junior }\end{array}$ & Oscar Wilde & Requiescat & 1 & \\
\hline $\begin{array}{l}\text { IV, ed. } 153 \text {, } \\
5 \text { de fevereiro } \\
\text { de } 1950\end{array}$ & Francês & $?$ & $\begin{array}{l}\text { Jacques } \\
\text { Maillart }\end{array}$ & O mar & 1 & \\
\hline $\begin{array}{l}\text { Suplemento } \\
\text { Letras \& Artes. } \\
\text { A Manhãa, ano } \\
\text { IV, ed. } 153 \text {, } \\
5 \text { de fevereiro } \\
\text { de } 1950\end{array}$ & Inglês & P.M.C & $\begin{array}{l}\text { Helen } \\
\text { Gardner }\end{array}$ & $\begin{array}{l}\text { Poeta maior } \\
\text { e poeta } \\
\text { menor }\end{array}$ & & 1 \\
\hline $\begin{array}{l}\text { Suplemento } \\
\text { Letras \& Artes. } \\
\text { A Manhã, ano } \\
\text { IV, ed. 156, } \\
5 \text { de março de } \\
1950\end{array}$ & Francês & $\begin{array}{l}\text { Raymundo } \\
\text { Magalhães } \\
\text { Junior }\end{array}$ & Rimbaud & $\begin{array}{l}\text { As } \\
\text { catadeiras } \\
\text { de piolho - } \\
\text { Les } \\
\text { chercheuse } \\
\text { s de poux }\end{array}$ & 1 & \\
\hline
\end{tabular}

Revista Texto Poético | ISSN: 1808-5385 | Vol. 20 (1o sem-2016) - p. 143 


\begin{tabular}{|c|c|c|c|c|c|c|}
\hline \multirow{2}{*}{$\begin{array}{l}\text { Suplemento } \\
\text { Letras \& Artes. } \\
\text { A Manhã, ano } \\
\text { IV, ed. 173, } \\
6 \text { de agosto de } \\
1950\end{array}$} & Alemão & $\begin{array}{l}\text { Herculano } \\
\text { de } \\
\text { Carvalho }\end{array}$ & $\begin{array}{l}\text { Nikolaus } \\
\text { Lenau }\end{array}$ & Céu triste & 1 & \\
\hline & Francês & $\begin{array}{l}\text { Osvaldo } \\
\text { Orico }\end{array}$ & Verhaeren & Fonterabia & 1 & \\
\hline $\begin{array}{l}\text { Suplemento } \\
\text { Letras \& Artes. } \\
\text { A Manhã, ano } \\
\text { IV, ed, 163, } \\
7 \text { de maio de } \\
1950\end{array}$ & & $?$ & $\begin{array}{l}\text { Georges } \\
\text { Fourest }\end{array}$ & $\begin{array}{l}\text { O Cid - Le } \\
\text { Cid }\end{array}$ & & \\
\hline $\begin{array}{l}\text { Suplemento } \\
\text { Letras \& Artes. } \\
\text { A Manhã, ano } \\
\text { IV, ed. } 150 \text {, } \\
8 \text { de janeiro de } \\
1949\end{array}$ & Alemão & $\begin{array}{l}\text { Adolfo } \\
\text { Casais } \\
\text { Monteiro }\end{array}$ & Franz Kafka & $\begin{array}{l}\text { A porta da } \\
\text { Lei }\end{array}$ & & 1 \\
\hline
\end{tabular}

Revista Texto Poético | ISSN: 1808-5385 | Vol. 20 (1o sem-2016) - p. 144 


\begin{tabular}{|c|c|c|c|c|}
\hline \multirow{4}{*}{$\begin{array}{l}\text { Suplemento } \\
\text { Letras \& Artes. } \\
\text { A Manhã, ano } \\
\text { IV, ed. } 170 \text {, } \\
4 \text { de julho de } \\
1950\end{array}$} & \multirow{4}{*}{ Inglês } & \multirow{4}{*}{$\begin{array}{l}\text { Péricles } \\
\text { Eugênio da } \\
\text { Silva } \\
\text { Ramos }\end{array}$} & \multirow{4}{*}{ Shakespeare } & Soneto I \\
\hline & & & & Soneto II \\
\hline & & & & Soneto III \\
\hline & & & & Soneto IV \\
\hline
\end{tabular}

Revista Texto Poético | ISSN: 1808-5385 | Vol. 20 (1o sem-2016) - p. 145 


\begin{tabular}{|c|c|c|c|c|c|c|}
\hline $\begin{array}{l}\text { Suplemento } \\
\text { Letras \& Artes. } \\
\text { A Manhã, ano } \\
\text { IV, ed } 170 \text {, } \\
9 \text { de julho de } \\
1950\end{array}$ & Romeno & $\begin{array}{l}\text { Maluh de } \\
\text { Ouro Preto }\end{array}$ & $\begin{array}{l}\text { Constantin } \\
\text { Virgil } \\
\text { Gheorghiu }\end{array}$ & $\begin{array}{l}\text { Em torno } \\
\text { da tradução } \\
\text { da } \\
\text { "Vigésima } \\
\text { quinta } \\
\text { hora" }\end{array}$ & & 1 \\
\hline $\begin{array}{l}\text { Suplemento } \\
\text { Letras \& Artes. } \\
\text { A Manhã, ano } \\
\text { IV, ed } 177, \\
10 \text { de outubro } \\
\text { de } 1950\end{array}$ & Francês & $\begin{array}{l}\text { Edmundo } \\
\text { Costa }\end{array}$ & $\begin{array}{l}\text { Paul } \\
\text { Verlaine }\end{array}$ & $\begin{array}{l}\text { A hora } \\
\text { propícia }\end{array}$ & 1 & \\
\hline $\begin{array}{l}\text { Suplemento } \\
\text { Letras \& Artes. } \\
\text { A Manhã, ano } \\
\text { IV, ed. } 178, \\
10 \text { de setembro } \\
\text { de } 1950\end{array}$ & Francês & $\begin{array}{l}\text { Guilherme } \\
\text { de Almeida }\end{array}$ & $\begin{array}{l}\text { Charles } \\
\text { Baudelaire }\end{array}$ & $\begin{array}{l}\text { Recolhime } \\
\text { nto }\end{array}$ & 1 & \\
\hline $\begin{array}{l}\text { Suplemento } \\
\text { Letras \& Artes. } \\
\text { A Manhã, ano } \\
\text { IV, ed. } 167 \text {, }\end{array}$ & Espanhol & - & Unamuno & $\begin{array}{l}\text { El Cristo de } \\
\text { Velasquez }\end{array}$ & 1 & \\
\hline
\end{tabular}

Revista Texto Poético I ISSN: 1808-5385 | Vol. 20 (1o sem-2016) - p. 146 


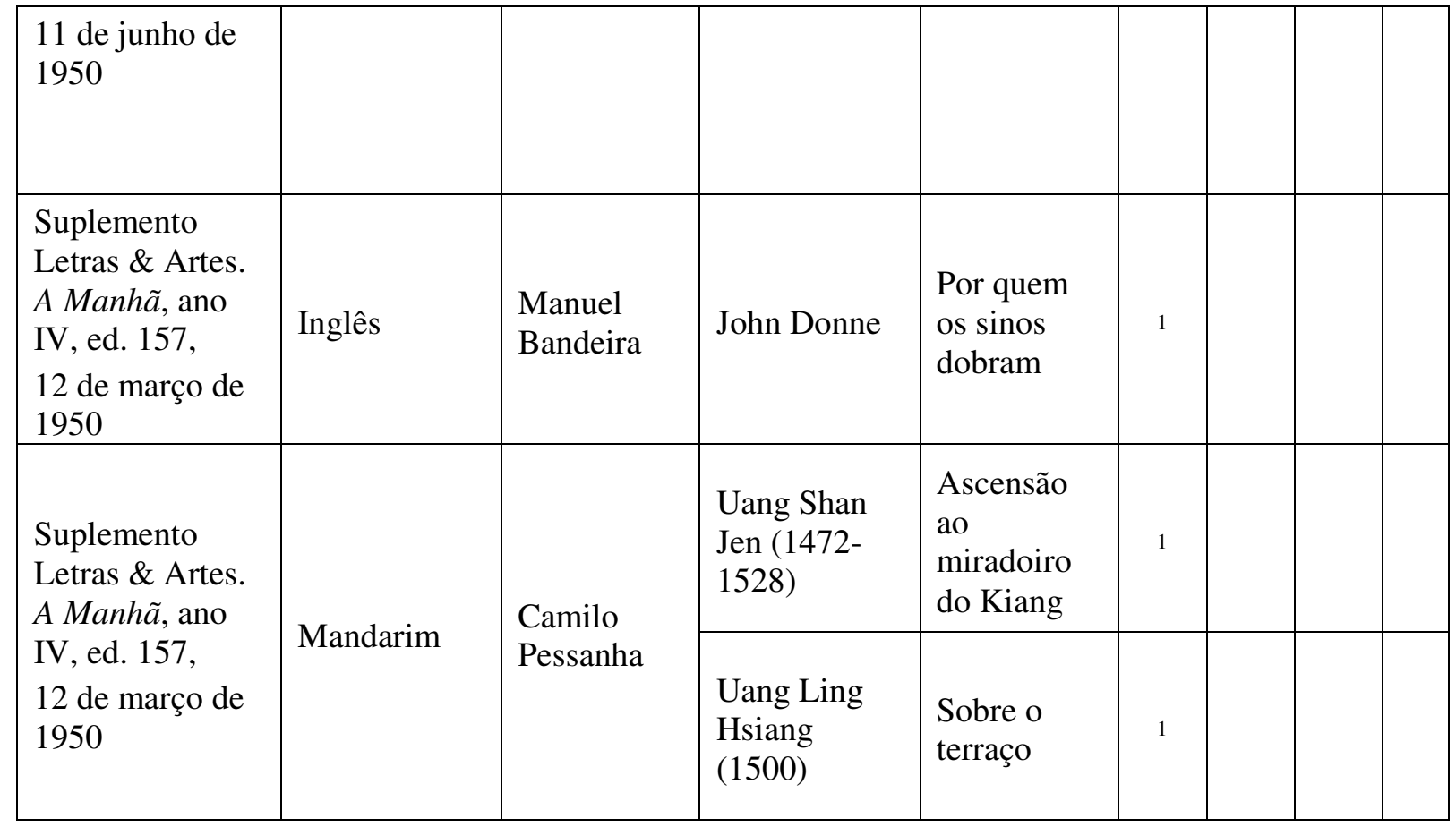

Revista Texto Poético | ISSN: 1808-5385 | Vol. 20 (1o sem-2016) - p. 147 


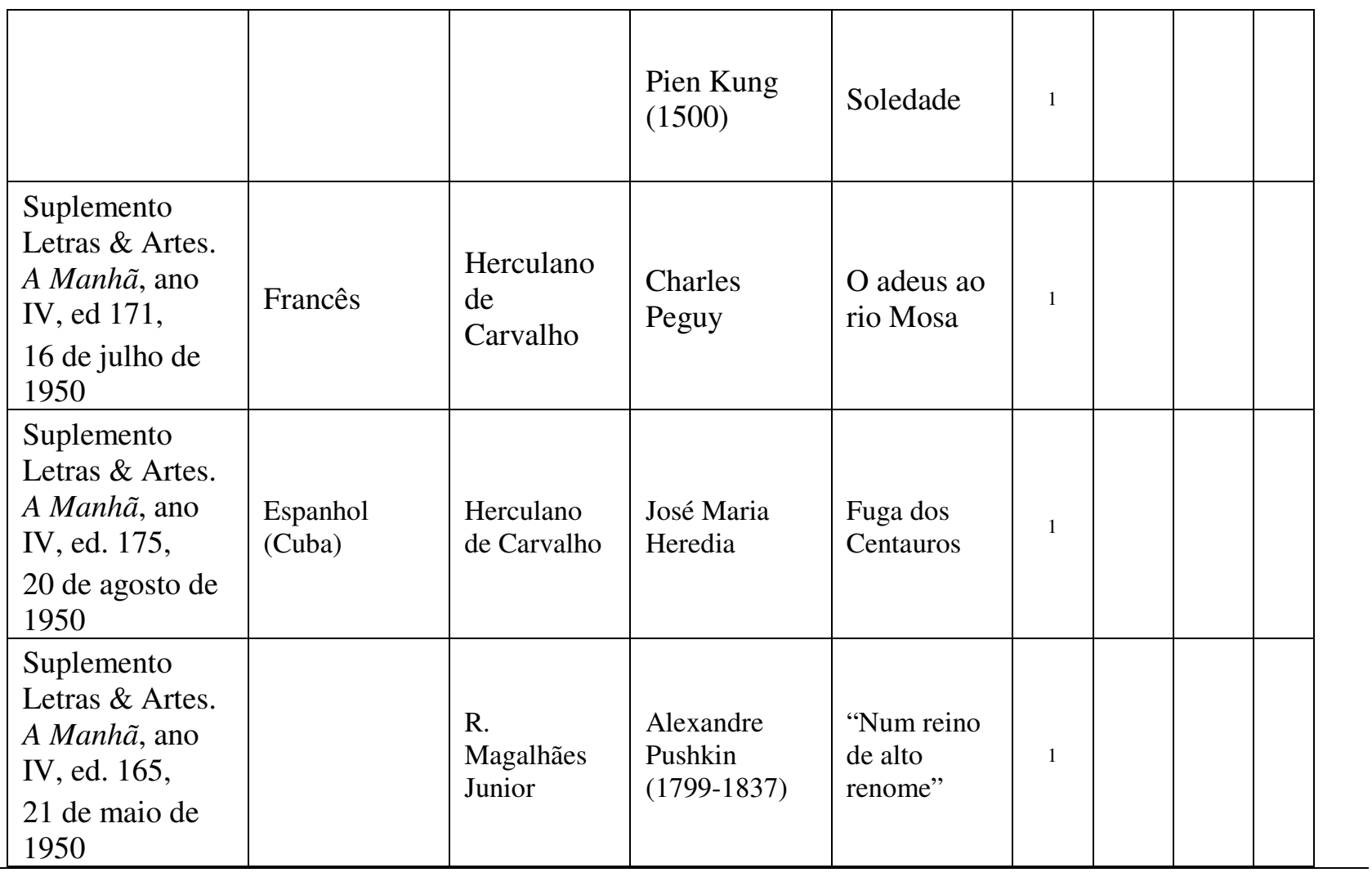

Revista Texto Poético | ISSN: 1808-5385 | Vol. 20 (1o sem-2016) - p. 148 


\begin{tabular}{|c|c|c|c|c|c|c|}
\hline \multirow{2}{*}{$\begin{array}{l}\text { Suplemento } \\
\text { Letras \& Artes. } \\
\text { A Manhã, ano } \\
\text { IV, ed. } 172 \text {, } \\
23 \text { de julho de } \\
1950\end{array}$} & Inglês & $\begin{array}{l}\text { Adolfo } \\
\text { Casais } \\
\text { Monteiro }\end{array}$ & $\begin{array}{l}\text { Langston } \\
\text { Hughes }\end{array}$ & "Sou negro" & 1 & \\
\hline & Francês & $\begin{array}{l}\text { Manuel } \\
\text { Bandeira }\end{array}$ & $\begin{array}{l}\text { Pierre de } \\
\text { Ronsard }\end{array}$ & $\begin{array}{l}\text { "Foi para } \\
\text { vós que } \\
\text { ontem colhi, } \\
\text { senhora" }\end{array}$ & 1 & \\
\hline $\begin{array}{l}\text { Suplemento } \\
\text { Letras \& Artes. } \\
\text { A Manhã , ano } \\
\text { IV, ed. } 165 \text {, } \\
25 \text { de maio de } \\
1950\end{array}$ & Inglês & $\begin{array}{l}\text { Lúcio } \\
\text { Bauerfeldt }\end{array}$ & $\begin{array}{l}\text { Somerset } \\
\text { Maugham }\end{array}$ & $\mathrm{O}$ amigo & & 1 \\
\hline
\end{tabular}

\section{1}


Quadro 6: esquematização das traduções publicadas no ano de 1951 no suplemento Letras \& Artes

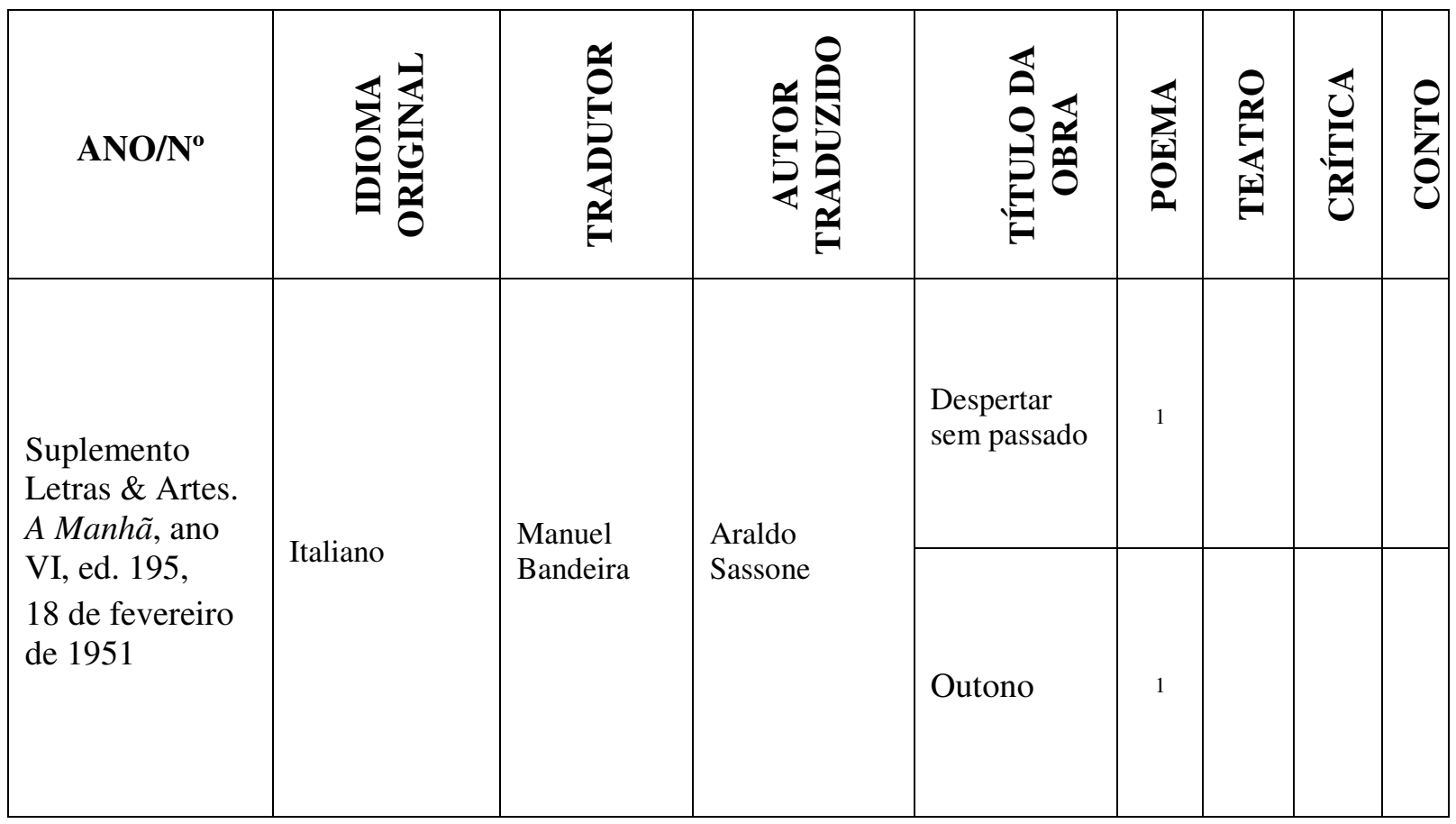

Revista Texto Poético | ISSN: 1808-5385 | Vol. 20 (1o sem-2016) - p. 150 


\begin{tabular}{|c|c|c|c|c|c|}
\hline & & & & Felicidade & 1 \\
\hline & & & & Santa Maria & 1 \\
\hline $\begin{array}{l}\text { Suplemento } \\
\text { Letras \& Artes. } \\
\text { A Manhã, ano } \\
\text { VI, ed. 204, } 24 \\
\text { de março de } \\
1951\end{array}$ & Italiano & $\begin{array}{l}\text { Manuel } \\
\text { Bandeira e } \\
\text { Luce } \\
\text { Ciancio }\end{array}$ & Mario Vitale & Vida & 1 \\
\hline
\end{tabular}

Revista Texto Poético | ISSN: 1808-5385 | Vol. 20 (1o sem-2016) - p. 151 


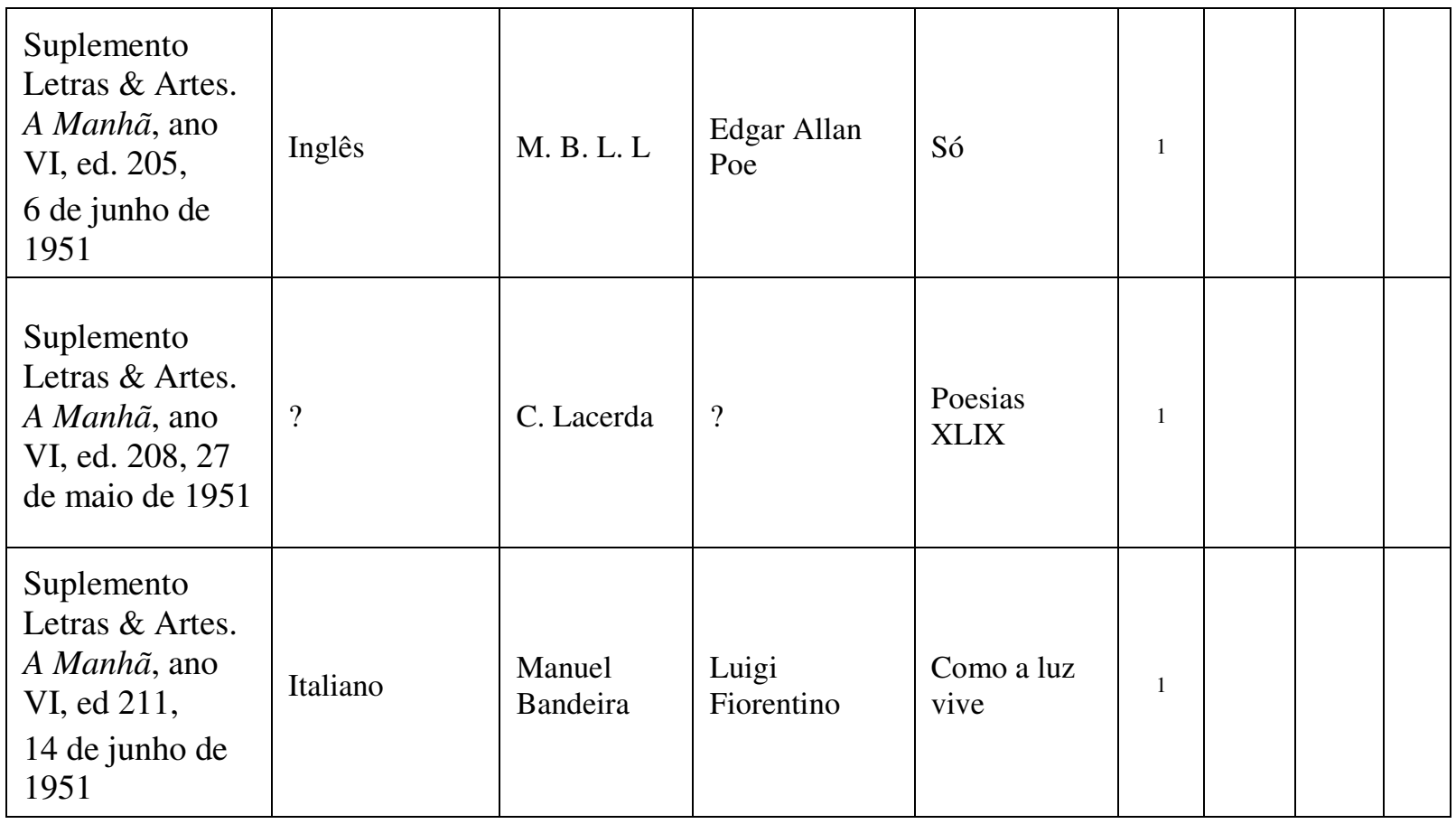

Revista Texto Poético | ISSN: 1808-5385 | Vol. 20 (1o sem-2016) - p. 152 


\begin{tabular}{|l|l|l|l|l|l|l|l|l|}
\hline & & & & & & & \\
& & Adeus sonho & 1 & & & \\
\hline $\begin{array}{l}\text { Suplemento } \\
\text { Letras \& Artes. } \\
\text { A Manha, ano } \\
\text { VI, ed. 222, 24 } \\
\text { de junho de } \\
1951\end{array}$ & Francês & $\begin{array}{l}\text { Osvaldo } \\
\text { Orico }\end{array}$ & $\begin{array}{l}\text { Emile } \\
\text { Verhaeren }\end{array}$ & O Amor & 1 & & & \\
\hline $\begin{array}{l}\text { Suplemento } \\
\text { Letras \& Artes. } \\
\text { A Manhã ano } \\
\text { VI, ed 213, } \\
1^{\circ} \text { de julho de } \\
1951\end{array}$ & Inglês & $\begin{array}{l}\text { Breno } \\
\text { Accioly }\end{array}$ & $\begin{array}{l}\text { Sherwood } \\
\text { Anderson }\end{array}$ & Aventura & & & & \\
\hline
\end{tabular}

Revista Texto Poético | ISSN: 1808-5385 | Vol. 20 (1o sem-2016) - p. 153 


\begin{tabular}{|c|c|c|c|c|c|c|}
\hline $\begin{array}{l}\text { Suplemento } \\
\text { Letras \& Artes. } \\
\text { A Manhã, ano } \\
\text { VI, ed. } 213 \text {, } \\
1^{\circ} \text { julho de } 1951\end{array}$ & Francês & $\begin{array}{l}\text { Paulo } \\
\text { Mendes } \\
\text { Camps }\end{array}$ & $\begin{array}{l}\text { Jacques } \\
\text { Prévert }\end{array}$ & $\begin{array}{l}\text { Como por } \\
\text { milagre }\end{array}$ & 1 & \\
\hline $\begin{array}{l}\text { Suplemento } \\
\text { Letras \& Artes. } \\
\text { A Manhã, ano } \\
\text { VI, ed. 191, } \\
2 \text { de janeiro de } \\
1951\end{array}$ & Espanhol & $\begin{array}{l}\text { Lygia } \\
\text { Fagundes } \\
\text { Telles }\end{array}$ & $\begin{array}{l}\text { Miguel de } \\
\text { Unamuno }\end{array}$ & João Manso & & 1 \\
\hline $\begin{array}{l}\text { Suplemento } \\
\text { Letras \& Artes. } \\
\text { A Manhã, ano } \\
\text { VI, ed. 194, } 11 \\
\text { de fevereiro de } \\
1951\end{array}$ & Francês & $\begin{array}{l}\text { Herculano } \\
\text { de } \\
\text { Carvalho }\end{array}$ & $\begin{array}{l}\text { Pierre de } \\
\text { Ronsard }\end{array}$ & $\begin{array}{l}\text { Soneto a } \\
\text { Helena }\end{array}$ & 1 & \\
\hline
\end{tabular}

Revista Texto Poético | ISSN: 1808-5385 | Vol. 20 (1o sem-2016) - p. 154 


\begin{tabular}{|c|c|c|c|c|c|c|}
\hline $\begin{array}{l}\text { Suplemento } \\
\text { Letras \& Artes. } \\
\text { A Manhã, ano } \\
\text { VI, ed. 197, } 11 \\
\text { de março de } \\
1951\end{array}$ & Espanhol & $\begin{array}{l}\text { Manuel } \\
\text { Bandeira }\end{array}$ & Rubén Dario & Sonatina & 1 & \\
\hline $\begin{array}{l}\text { Suplemento } \\
\text { Letras \& Artes. } \\
\text { A Manhã, ano } \\
\text { VI, ed. } 190 \text {, } \\
7 \text { de janeiro de } \\
1951\end{array}$ & Inglês & $\begin{array}{l}\text { Manuel } \\
\text { Bandeira }\end{array}$ & $\begin{array}{l}\text { Elizabeth } \\
\text { Barrett } \\
\text { Browning }\end{array}$ & Soneto & 1 & \\
\hline $\begin{array}{l}\text { Suplemento } \\
\text { Letras \& Artes. } \\
\text { A Manhã, ano } \\
\text { VI, ed. } 223 \text {, } \\
16 \text { de setembro } \\
\text { de } 1951\end{array}$ & Italiano & B.B & $\begin{array}{l}\text { Ignazio } \\
\text { Silone }\end{array}$ & O hóspede & & 1 \\
\hline
\end{tabular}

Revista Texto Poético | ISSN: 1808-5385 | Vol. 20 (1o sem-2016) - p. 155 


\begin{tabular}{|c|c|c|c|c|c|c|}
\hline $\begin{array}{l}\text { Suplemento } \\
\text { Letras \& Artes. } \\
\text { A Manhã, ano } \\
\text { VI, ed. } 223,16 \\
\text { de setembro de } \\
1951\end{array}$ & Inglês & $\begin{array}{l}\text { Bezerra de } \\
\text { Menezes }\end{array}$ & $\begin{array}{l}\text { H. W } \\
\text { Longfellow }\end{array}$ & A catedral & 1 & \\
\hline $\begin{array}{l}\text { Suplemento } \\
\text { Letras \& Artes. } \\
\text { A Manhã, ano } \\
\text { VI, ed. } 228, \\
4 \text { de novembro } \\
\text { de } 1951\end{array}$ & Espanhol & $\begin{array}{l}\text { Breno } \\
\text { Accioly }\end{array}$ & $\begin{array}{l}\text { Miguel } \\
\text { Unamuno }\end{array}$ & As tesouras & & 1 \\
\hline $\begin{array}{l}\text { Suplemento } \\
\text { Letras \& Artes. } \\
\text { A Manhã, ano } \\
\text { VI, ed. } 223,16 \\
\text { de setembro de } \\
1951\end{array}$ & Alemão & $\begin{array}{l}\text { João } \\
\text { Accioli }\end{array}$ & $\begin{array}{l}\text { Rainer Maria } \\
\text { Rilke }\end{array}$ & $\begin{array}{l}\text { Outonal - } \\
\text { Herbststim } \\
\text { mung }\end{array}$ & 1 & \\
\hline
\end{tabular}

Revista Texto Poético | ISSN: 1808-5385 | Vol. 20 (1o sem-2016) - p. 156 


\begin{tabular}{|c|c|c|c|c|c|c|}
\hline $\begin{array}{l}\text { Suplemento } \\
\text { Letras \& Artes. } \\
\text { A Manhã, ano } \\
\text { VI, ed. 224, } 23 \\
\text { de setembro de } \\
1951\end{array}$ & Espanhol & $\begin{array}{l}\text { Carmen } \\
\text { Mendes } \\
\text { Viana }\end{array}$ & $\begin{array}{l}\text { Elisabeth } \\
\text { Mulder }\end{array}$ & $\begin{array}{l}\text { A } \\
\text { adolescente } \\
\text { de pedra }\end{array}$ & & 1 \\
\hline $\begin{array}{l}\text { Suplemento } \\
\text { Letras \& Artes. } \\
\text { A Manhã, ano } \\
\text { VI, ed. } 226 \text {, } \\
18 \text { de outubro } \\
\text { de } 1951\end{array}$ & Alemão & $\begin{array}{l}\text { João } \\
\text { Accioli }\end{array}$ & Georg Trakl & $\begin{array}{l}\text { Canto da } \\
\text { noite - } \\
\text { Nachtlied }\end{array}$ & 1 & \\
\hline $\begin{array}{l}\text { Suplemento } \\
\text { Letras \& Artes. } \\
\text { A Manhã, ano } \\
\text { VI, ed. } 216,22 \\
\text { de julho de } 1951\end{array}$ & $\begin{array}{l}\text { Espanhol } \\
\text { (Uruguai) }\end{array}$ & $\begin{array}{l}\text { Breno } \\
\text { Accioly }\end{array}$ & $\begin{array}{c}\text { Horacio } \\
\text { Quiroga }\end{array}$ & Barcos & & 1 \\
\hline
\end{tabular}

Revista Texto Poético | ISSN: 1808-5385 | Vol. 20 (1o sem-2016) - p. 157 


\section{2}

Quadro 7: esquematização das traduções publicadas no ano de 1952 no suplemento Letras \& Artes

\begin{tabular}{|c|c|c|c|c|c|c|c|c|}
\hline $\mathrm{ANO} / \mathbf{N}^{\circ}$ & 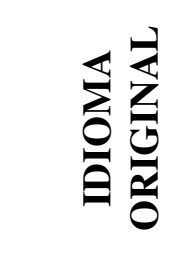 & 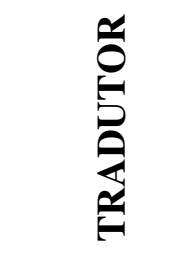 & 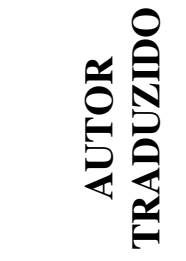 & 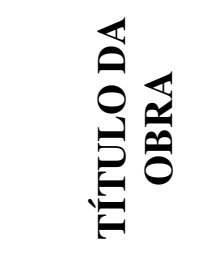 & $\begin{array}{l}\sum_{\pi=1}^{\sharp} \\
0 \\
0\end{array}$ & 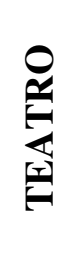 & 㞯 & ○ \\
\hline $\begin{array}{l}\text { Suplemento } \\
\text { Letras \& } \\
\text { Artes. A } \\
\text { Manhã, ano } \\
\text { VII, ed. 256, } \\
13 \text { de julho de } \\
1952\end{array}$ & Italiano & $\begin{array}{l}\text { Vicente } \\
\text { Augustus } \\
\text { Carnicelli }\end{array}$ & $\begin{array}{l}\text { Luigi } \\
\text { Fiorentino }\end{array}$ & $\begin{array}{l}\text { Doce alento } \\
\text { tépido do } \\
\text { mar }\end{array}$ & 1 & & & \\
\hline
\end{tabular}




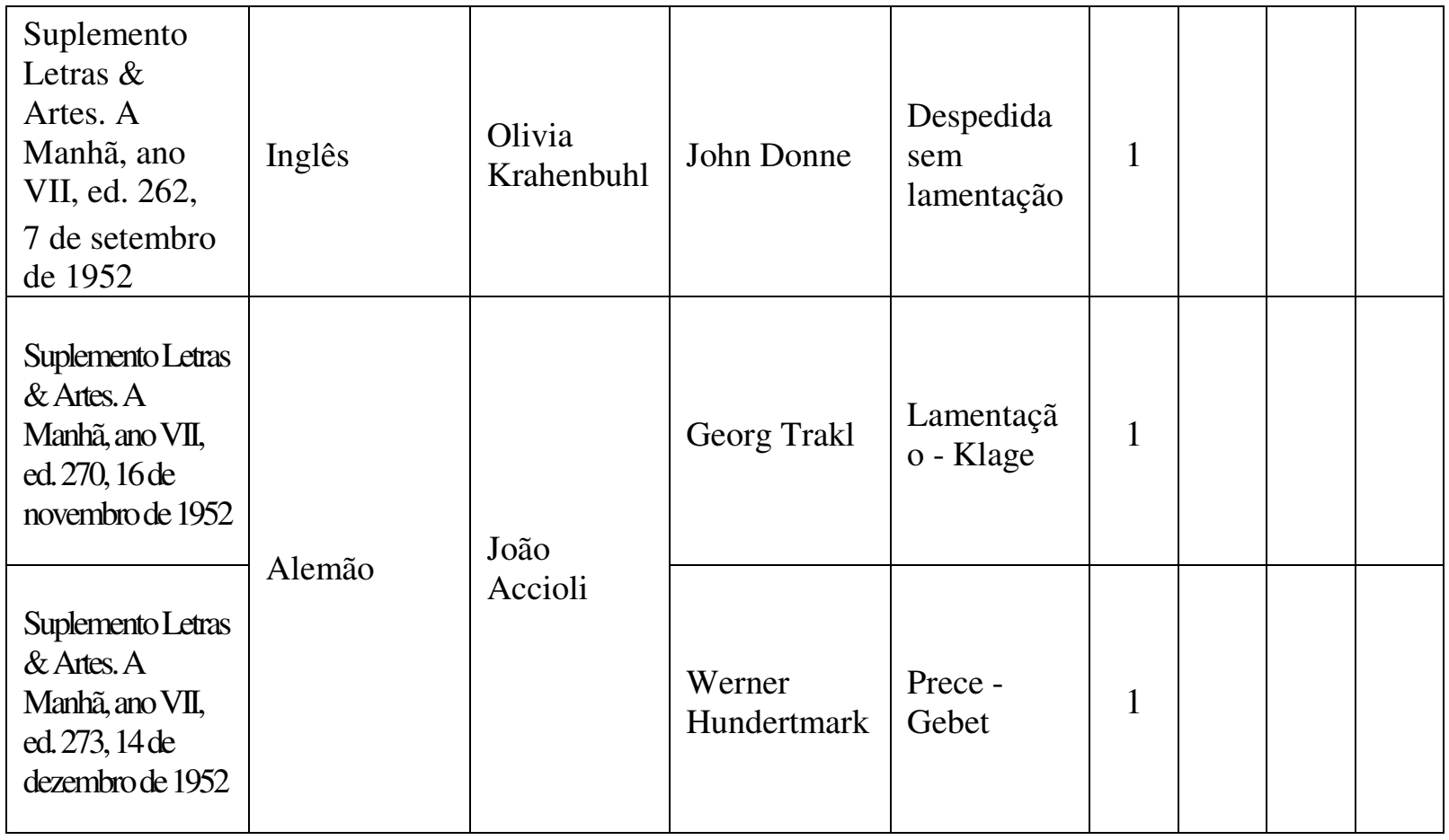

Revista Texto Poético | ISSN: 1808-5385 | Vol. 20 (1o sem-2016) - p. 159 


\section{3}

Quadro 8: esquematização das traduções publicadas no ano de 1953 no suplemento Letras \& Artes

\begin{tabular}{|c|c|c|c|c|c|c|c|c|}
\hline $\mathrm{ANO} / \mathrm{N}^{\circ}$ & 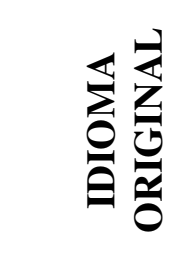 & 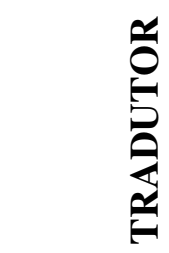 & 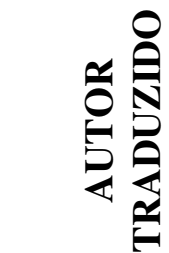 & 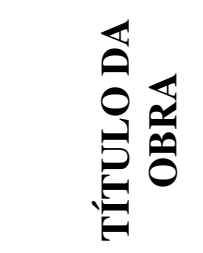 & $\sum_{\substack{1 \\
0}}^{\}$ & 赵 & 忌 & \begin{tabular}{l}
0 \\
\hdashline \\
0 \\
0
\end{tabular} \\
\hline $\begin{array}{l}\text { Suplemento } \\
\text { Letras \& } \\
\text { Artes. A } \\
\text { Manhãa, ano } \\
\text { VIII, ed. } \\
276,11 \text { de } \\
\text { janeiro de } \\
1953\end{array}$ & $\begin{array}{l}\text { Espanhol } \\
\text { (Cuba) }\end{array}$ & $\begin{array}{l}\text { Vicente } \\
\text { Jusselino }\end{array}$ & Heredia & $\begin{array}{l}\text { Os } \\
\text { conquistado } \\
\text { res }\end{array}$ & 1 & & & \\
\hline
\end{tabular}




\begin{tabular}{|c|c|c|c|c|c|c|}
\hline $\begin{array}{l}\text { Suplemento } \\
\text { Letras \& } \\
\text { Artes. } A \\
\text { Manhã, ano } \\
\text { VIII, ed. } \\
279,8 \text { de } \\
\text { fevereiro } \\
\text { de } 1953\end{array}$ & Alemão & João Accioli & Goethe & $\begin{array}{l}\text { Alegre e } \\
\text { triste - } \\
\text { Freudvoll } \\
\text { und leidvoll }\end{array}$ & 1 & \\
\hline $\begin{array}{l}\text { Suplemento } \\
\text { Letras \& } \\
\text { Artes. A } \\
\text { Manhã, ano } \\
\text { VIII, ed. } \\
281,1^{\circ} \text { de } \\
\text { março de } \\
1953\end{array}$ & Italiano & $\begin{array}{l}\text { Vicente } \\
\text { Augustus } \\
\text { Carnicelli }\end{array}$ & $\begin{array}{l}\text { Salvatore } \\
\text { Quasimodo }\end{array}$ & $\begin{array}{l}\text { Repouso da } \\
\text { erva }\end{array}$ & 1 & \\
\hline $\begin{array}{l}\text { Suplemento } \\
\text { Letras \& } \\
\text { Artes. A } \\
\text { Manhã, ano } \\
\text { VIII, ed } \\
292 \text {, } \\
7 \text { de junho }\end{array}$ & Espanhol & Terezinha Eboli & $\begin{array}{l}\text { Sergio } \\
\text { Honorato }\end{array}$ & Interior & & 1 \\
\hline
\end{tabular}

Revista Texto Poético | ISSN: 1808-5385 | Vol. 20 (1o sem-2016) - p. 161 


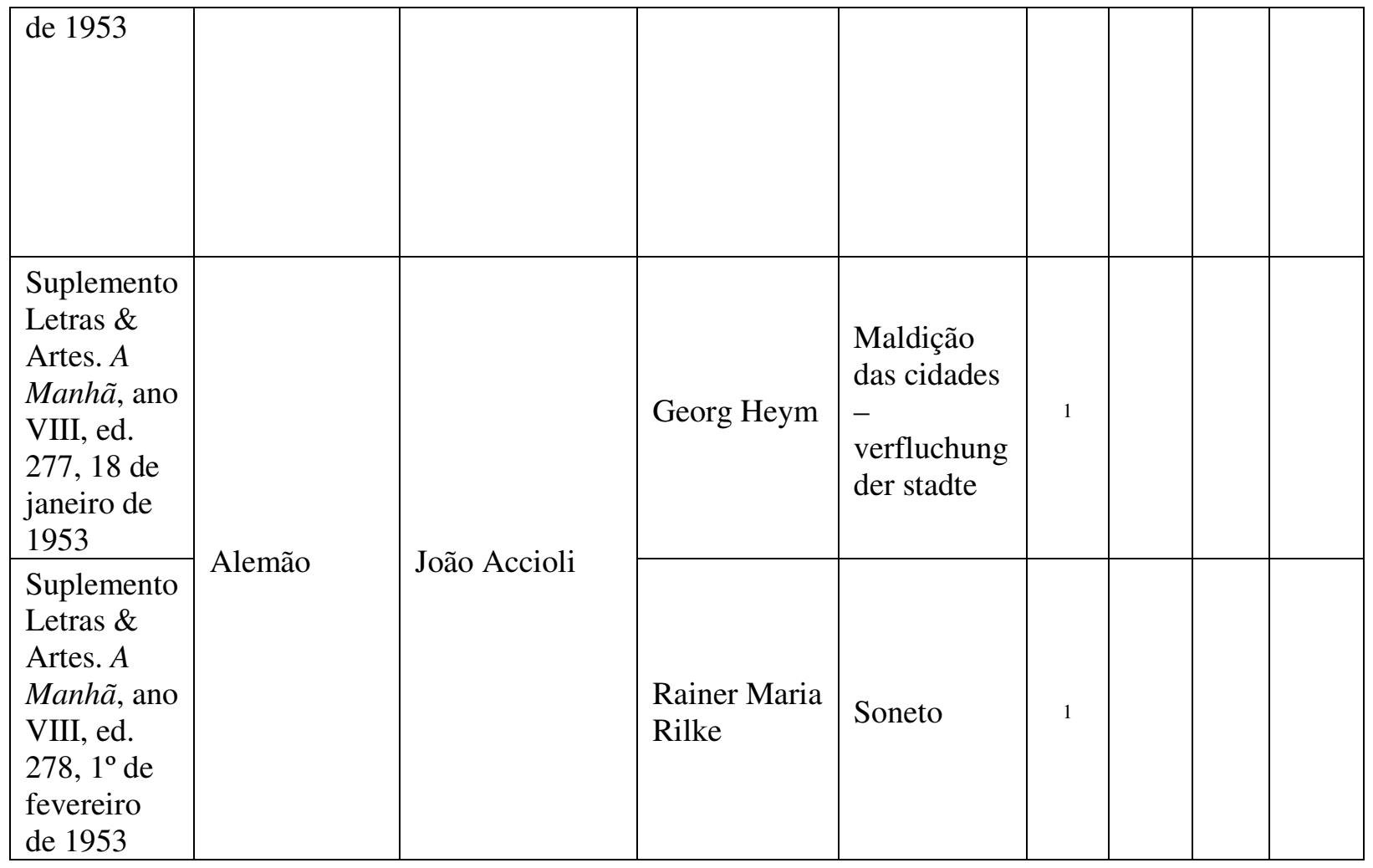

Revista Texto Poético | ISSN: 1808-5385 | Vol. 20 (1o sem-2016) - p. 162 


\begin{tabular}{|l|l|l|l|l|l|l|l|l|}
\hline $\begin{array}{l}\text { Suplemento } \\
\text { Letras \& }\end{array}$ & & & & & & & \\
Artes. $A$ & & Vicente & Salvatore & Nel senso & & & \\
Manhã, ano & Italiano & Augustus & Quasimodo & di morte & & & \\
VIII, ed. & & Carnicelli & & & & \\
283,15 de & & & & & & \\
março de & & & & & & \\
1953 & & & & & & \\
\hline
\end{tabular}




\section{4}

Quadro 9: esquematização das traduções publicadas no ano de 1954 no suplemento Letras \& Artes

\begin{tabular}{|c|c|c|c|c|c|c|c|c|}
\hline $\mathrm{ANO} / \mathbf{N}^{\circ}$ & 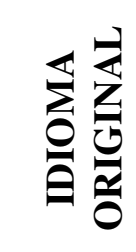 & 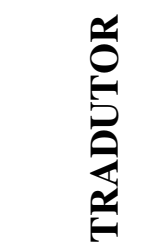 & 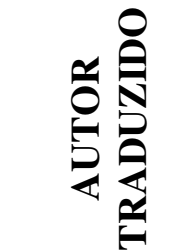 & 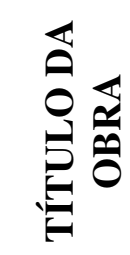 & 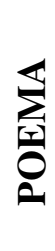 & 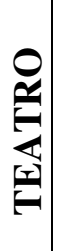 & 苂 & 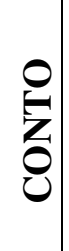 \\
\hline $\begin{array}{l}\text { Suplemento Letras \& } \\
\text { Artes. A Manhãa, ano } \\
\text { VIII, ed. } 298,11 \text { de } \\
\text { maio de } 1954\end{array}$ & Inglês & $\begin{array}{l}\text { Olivia } \\
\text { Krahenbuhl }\end{array}$ & $\begin{array}{l}\text { Emily } \\
\text { Dickinson }\end{array}$ & Fome & 1 & & & \\
\hline
\end{tabular}

Revista Texto Poético | ISSN: 1808-5385 | Vol. 20 (1o sem-2016) - p. 164 


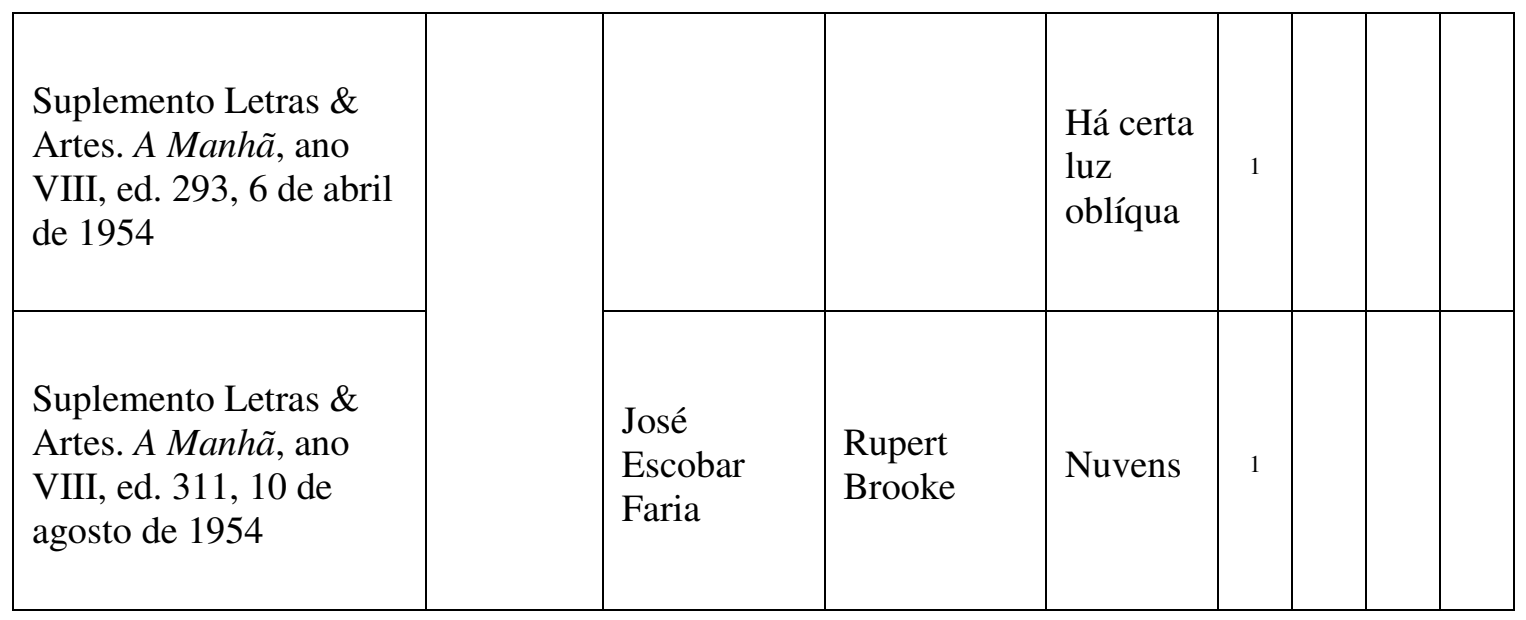

Revista Texto Poético | ISSN: 1808-5385 | Vol. 20 (1o sem-2016) - p. 165 


\section{Referências}

BHABHA, Homi. O local da cultura. Belo Horizonte: Ed: UFMG, 2013.

COSTA, Walter Carlos, GUIMARÃES, Mayara, LEAL, Izabela. No horizonte do provisório: ensaios sobre tradução. Rio de Janeiro: Letras, 2013.

EAGLETON, Terry. A ideia de cultura. São Paulo: Editora Unesp, 2011.

LEFEVERE, André. Tradução, reescrita e manipulação da fama literária. São Paulo: Edusc, 2007. 